TITLE:

\title{
Nitrate-use traits of understory plants as potential regulators of vegetation distribution on a slope in a Japanese cedar plantation
}

\section{AUTHOR(S):}

Koyama, Lina; Hirobe, Muneto; Koba, Keisuke; Tokuchi, Naoko

\section{CITATION:}

Koyama, Lina ... [et al]. Nitrate-use traits of understory plants as potential regulators of vegetation distribution on a slope in a Japanese cedar plantation. Plant and Soil 2013, 362(1-2): 119-134

\section{ISSUE DATE:}

2013-01

URL:

http://hdl.handle.net/2433/168707

\section{RIGHT:}

The final publication is available at www.springerlink.com; This is not the published version. Please cite only the published version.; この論文 は出版社版でありません。引用の際には出版社版をご確認ご利用くだ さい。 


\section{TITLE}

Nitrate-use traits of understory plants as potential regulators of vegetation distribution on a slope in a Japanese cedar plantation

\section{NAMES OF AUTHORS:}

* Lina KOYAMA ${ }^{1,2}$, Muneto HIROBE ${ }^{1,3}$, Keisuke KOBA ${ }^{1,4}$ and Naoko TOKUCHI ${ }^{1,5}$

\section{AFFILIATIONS OF AUTHORS:}

1. Graduate School of Agriculture, Kyoto University, Kyoto, 606-8502, Japan.

2. Graduate School of Informatics, Kyoto University, Kyoto, 606-8501, Japan.

3. Graduate School of Environmental Science, Okayama University, 1-1-1

Tsushima-Naka, Okayama, 700-8530, Japan

4. Faculty of Agriculture, Tokyo University of Agriculture and Technology, 3-5-8,

Saiwai-cho, Fuchu city, 183-8509, Japan

5. Field Science Education and Research Center, Kyoto University, Kyoto 606-8502 Japan

\section{CORRESPONDING AUTHOR:}

KOYAMA, Lina

Cover address: Laboratory of Biosphere Informatics,

Graduate School of Informatics, Kyoto University

Kyoto, 606-8501, Japan.

E-mail: $\quad$ linak@bre.soc.i.kyoto-u.ac.jp

Phone / Fax: $\quad$ +81757533297/+81757533133 


\section{ABSTRACT}

[Background and Aims]

Plant physiological traits and their relation to soil $\mathrm{N}$ availability was investigated as regulators of the distribution of understory shrub species along a slope in a Japanese cedar (Cryptomeria japonica) plantation in central Japan.

[Methods]

At the study site, previous studies demonstrated that both net and gross soil nitrification rates are high on the lower slope and there are dramatic declines in different sections of the slope gradient. We examined the distributions of understory plant species and their nitrate $\left(\mathrm{NO}_{3}{ }^{-} \mathrm{N}\right)$ use traits, and compared the results with the soil traits.

[Results]

Our results show that boundaries between different dominant understory species correspond to boundaries between different soil types. Leucosceptrum stellipilum occurs on soil with high net and gross nitrification rates. Hydrangea hirta is dominant on soil with high net and low gross nitrification rates. Pieris japonica occurs on soil with very low net and gross nitrification rates. Dominant understory species have species-specific physiological traits in their use of $\mathrm{NO}_{3}^{-}-\mathrm{N}$. Pieris japonica lacks the capacity to use $\mathrm{NO}_{3}^{-}-\mathrm{N}$ as a N source, but other species do use $\mathrm{NO}_{3}^{-}-\mathrm{N}$. Lindera triloba, whose distribution is unrelated to soil $\mathrm{NO}_{3}{ }^{-}-\mathrm{N}$ availability, changes the extent to which it uses $\mathrm{NO}_{3}{ }^{-}-\mathrm{N}$ in response to soil $\mathrm{NO}_{3}{ }^{-} \mathrm{N}$ availability.

[Conclusions]

Our results indicate that differences in the physiological capabilities and adaptabilities of plant species in using $\mathrm{NO}_{3}^{-}-\mathrm{N}$ as a $\mathrm{N}$ source regulate their distribution ranges. The identity of the major form of available soil $\mathrm{N}$ is therefore an environmental factor that influences plant distributions.

\section{KEYWORDS}

Nitrate $\left(\mathrm{NO}_{3}{ }^{-}-\mathrm{N}\right)$; nitrate reductase activity (NRA); soil $\mathrm{NO}_{3}^{-}-\mathrm{N}$ availability; spatial distribution; understory 


\section{INTRODUCTION}

Topography is among the factors that influence plant distributions on scales of tens to hundreds of meters. Plants often have species-specific distribution patterns along landscape slopes, with some occurring preferentially on upper slopes, others on lower slopes, and yet others spread across the whole gradient. Slope topography does not directly regulate species' distributions; environmental factors that affect plant performance vary across different sections of slope. Soil moisture, nutrient availability (Enoki et al. 1997; Giesler et al. 1998; Small and McCarthy 2005), and ground surface disturbance (Enoki 2003; Sakai and Ohsawa 1993, 1994) are all regulators of plant growth that change with topographic features. Accordingly, there are different types of vegetation on different sections of slope.

Previous analyses of soil $\mathrm{N}$ transformations at the site of the present study distinguished spatial patterns of different soil types across a selected gradient (Hirobe et al. 1998, 2001; Tokuchi et al. 1999, 2000). On this gradient, net and gross nitrification rates are high and very low on the lower and upper slope sections, respectively, while net $\mathrm{N}$ mineralization rates show no clear gradient along the slope; the soil $\mathrm{NO}_{3}{ }^{-} \mathrm{N}$ pool is larger on the lower slope than on the upper section, while the size of the total inorganic $\mathrm{N}$ pool does not change significantly along the gradient; and dramatic changes in $\mathrm{NO}_{3}{ }^{-}-\mathrm{N}$ availability occur only in a narrow section of the slope. The changes in soil types across topographic gradients occur elsewhere in connection with the gradient of environmental condition such as soil moisture contents (Giesler et al. 1998; Velthof et al. 2000; Tateno and Takeda 2003). However, the gradient changes in major $\mathrm{N}$ forms are especially dramatic at our chosen study site; $\mathrm{NO}_{3}{ }^{-} \mathrm{N}$ is the major inorganic $\mathrm{N}$ species on the lower part of the slope, and ammonium $\left(\mathrm{NH}_{4}{ }^{+}-\mathrm{N}\right)$ is the major form on the upper slope.

Differences in the major forms of available $\mathrm{N}$ in soil likely have a strong impact on plants because there are intrinsic differences between plant metabolic processes that assimilate $\mathrm{NO}_{3}{ }^{-}-\mathrm{N}$ and $\mathrm{NH}_{4}{ }^{+}-\mathrm{N}$. Ammonium is directly assimilated into an organic form, whereas $\mathrm{NO}_{3}{ }^{-} \mathrm{N}$ must first be reduced to $\mathrm{NH}_{4}{ }^{+} \mathrm{N}$ by enzymes such as nitrate reductase (NR) before incorporation into organic $\mathrm{N}$. NR is a substrate-inducible enzyme, and the capacity to induce NR differs markedly among plant species; some are unable to induce $\mathrm{NR}$, a necessary requirement for the utilization of $\mathrm{NO}_{3}{ }^{-} \mathrm{N}$ as a $\mathrm{N}$ source (Al Gharbi and Hipkin 1984; Gebauer and Schulze 1997; Gebauer et al. 1988; Smirnoff et al. 1984).

The change of major form of soil inorganic $\mathrm{N}$ with forest succession has been considered as a regulating factor of species establishment in each successional stage through the plant physiological traits about N use (Kronzucker et al. 1997; 2003; Min et al. 1998). Taking into account the spatial heterogeneity of soil $\mathrm{NO}_{3}{ }^{-}-\mathrm{N}$ availability and the species-specific mechanisms of $\mathrm{NO}_{3}{ }^{-}-\mathrm{N}$ use, it seems very likely that the spatial distribution of different types of soils is a major factor regulating the distribution of plant species across landscapes. However, major N source identity has yet to be 
regarded as an important regulating factor in coincidental plant distribution. In this study, we considered soil $\mathrm{N}$ transformation as a factor in plant distributions by examining whether plant species had different distribution patterns related to their different responses to the quantity and quality of available soil $\mathrm{N}$. In addition, we examined the possibility that plant species' distributions influence soil $\mathrm{N}$ transformation; we postulated that the underlying mechanism lies in differences in litter organic composition among species, which in turn should influence soil $\mathrm{N}$ dynamics (Bengtson et al. 2006; Ferrari 1999).

We conducted a vegetation survey of understory species along a slope gradient for comparison with the spatial distribution of soil $\mathrm{N}$ transformation mechanisms; we also measured other environmental conditions including light, soil $\mathrm{pH}$, and soil moisture. Dominant understory species were chosen for examination of $\mathrm{NO}_{3}{ }^{-}-\mathrm{N}$ use. To do this, we measured $\mathrm{N}$ concentration, $\mathrm{NO}_{3}{ }^{-} \mathrm{N}$ concentration, and in vivo nitrate reductase activity (NRA) in plant leaves. The presence of $\mathrm{NO}_{3}{ }^{-} \mathrm{-N}$ within plant tissue is evidence of $\mathrm{NO}_{3}{ }^{-}-\mathrm{N}$ uptake, as plants generally do not have the capacity to synthesize $\mathrm{NO}_{3}^{-}-\mathrm{N}$ except that certain legume species is observed generating nitrification (Hipkin et al. 2004). In vivo NRA is an important indicator of plant $\mathrm{NO}_{3}{ }^{-}-\mathrm{N}$ use, since the reduction of $\mathrm{NO}_{3}{ }^{-}-\mathrm{N}$ to nitrite $\left(\mathrm{NO}_{2}^{-}-\mathrm{N}\right)$ by $\mathrm{NR}$ is the first step and the rate-limiting mechanism in the whole sequence of $\mathrm{NO}_{3}{ }^{-}$ -N assimilation processes (Beevers and Hageman 1969; Tischner 2000). Concurrent with plant measurements, we also measured inorganic $\mathrm{N}\left(\mathrm{NH}_{4}{ }^{+}-\mathrm{N}\right.$ and $\left.\mathrm{NO}_{3}{ }^{-} \mathrm{-N}\right)$ pool sizes in the soil samples associated with each sample plant. Measurements were made through the growing period to record seasonal patterns. By comparing spatiotemporal changes in plant leaf traits with soil inorganic $\mathrm{N}$ pool sizes, we were able to discern different species' responses and physiological adaptations to $\mathrm{NO}_{3}{ }^{-} \mathrm{N}$ use across the gradient of changing soil inorganic $\mathrm{N}$ pool sizes.

\section{MATERIALS AND METHODS}

\section{Study site}

This study site is located in a plantation of Japanese cedar (Cryptomeria japonica D. Don; ca. 50 yr old) on Mt. Ryuoh in central Japan $\left(35^{\circ} 1^{\prime} \mathrm{N}, 136^{\circ} 20^{\prime} \mathrm{E}\right)$. The mean annual temperature and mean annual precipitation at the site are $10^{\circ} \mathrm{C}$ and $2050 \mathrm{~mm}$, respectively (Tokuchi et al. 1993).

The site is on an approximately 135-m-long south-facing slope; elevation ranges from 765 to $851 \mathrm{~m}$. Mean slope inclination is $38.5^{\circ}$ (range: $25.3-50.4^{\circ}$ ) [Fig. 1(a)]. The slope is slightly steeper in the central portion than in other sections. The change in inclination is gradual on the lower slope, but uneven in the upper section. The light conditions for understory species were measured based on the canopy cover ratio determined from hemispherical photographs taken over understory crowns [Fig. 1(b)]. The canopy cover ratio was highest at the bottom of the slope and declined gradually upslope, ranging from 75.21 to $98.36 \%$. There were some canopy gaps that had low canopy cover ratios. The change in canopy cover ratio along the slope was presumably due to changes in the size of canopy 
trees (C. japonica) [Fig. 1(c); Tokuchi et al. 1999]. The mean diameter at breast height (DBH) of $C$. japonica. at the study site was $190 \pm 57 \mathrm{~mm}$, and it was higher on the lower slope than elsewhere. In contrast to aboveground biomass, the fine root biomass of $C$. japonica was lowest on the lower slope [Fig. 1(c); Kasuya and Shimada 1996]. The organic layer was thicker on the upper slope than lower down [Fig. 1(d); Hobara and Tokuchi 1998]. Soil pH was highest on the lower slope, and soil acidity changed gradually [Fig. 1(e); Hirobe et al. 1998; Yoshida unpublished data]. Hirobe et al. (1998) demonstrated a gradual decrease in soil water content with increasing distance from the base of the slope, although previous studies reported highly fluctuating soil water content along the slope [Fig. 1(f); Kasuya and Shimada 1996; Yoshida unpublished data].

In contrast to other environmental factors that change rather gradually along the slope, soil $\mathrm{N}$ transformation processes change dramatically in short sections of the gradient (Hirobe et al.1998; Tokuchi et al. 2000). Net soil nitrification rates were found to be much higher on the lower slope than at higher elevations, while net soil $\mathrm{N}$ mineralization rates were not clearly related to position on the gradient [Fig. 1(h)]. Net nitrification rates changed dramatically between $60 \mathrm{~m}$ and $75 \mathrm{~m}$ upward from the base of the slope [see also Fig. 3(d); Hirobe et al. 1998]. Gross nitrification rates were also much higher on the lower slope than at higher elevations [Fig. 1(g); Tokuchi et al. 2000]. However, the section of the slope where the gross nitrification rate changed did not correspond to the zone where the net nitrification rate changed. Hence, the gradient was classifiable into three categories by soil nitrification rates: the lower slope, where both net and gross soil nitrification rates were high; the mid slope, where the net nitrification rate was high and the gross nitrification rate low; and the upper slope, where both net and gross nitrification rates were low.

\section{Vegetation study}

To survey understory vegetation, a $1 \times 132-\mathrm{m}$ study plot (plot A) was deployed along the length of the slope. The plot was divided into 44 subplots each measuring $1 \times 3 \mathrm{~m}$. Species' identities and the numbers of stems were recorded for plants $>10 \mathrm{~cm}$ in height in each subplot. Nomenclature followed Ohwi and Kitagawa (1983).

Hirobe et al. (1998) concluded that the boundary zone between mid and upper slopes comprises soil patches that are characterized by two completely different net nitrification rates, with no gradational change in soil properties. Accordingly, we set up another study plot (plot B) to overlap the boundary between the mid and upper slopes (45-90 m upward from the base of the slope) to observe relationships between the distributions of soil properties and understory plant species. The plot, which measured $5 \times 45 \mathrm{~m}$, was divided into 900 subplots, each $0.5 \times 0.5 \mathrm{~m}$, within which we recorded species' identities and the numbers of stems for plants $>10 \mathrm{~cm}$ in height.

Spatial analyses were performed for selected shrub species based on the results of our vegetation study in plot $\mathrm{B}$. The spatial traits of understory vegetation were described by using spatial 
analysis by distance indices (SADIE; Perry, 1995). For this procedure, we used understory shrub stem numbers in each $0.5 \times 0.5-\mathrm{m}$ subplot. The degree of non-randomness in spatial distribution was quantified by the index of aggregation $\left(I_{a} ;\right.$ Perry, 1995). In general, a spatially aggregated data set has $I_{a}>1$, a spatially random data set has $I_{a}=1$, and a spatially regular data set has $I_{a}<1$. Dimensionless indices of clustering ( $v_{i}$ and $v_{j}$ ) were calculated, and the means of $v_{i}$ and $v_{j}$ were used to quantify the degree of data clustering into patches (areas with above-average density) and gaps (areas with belowaverage density). Based on the clustering indices, we calculated the index of local association $(X)$ to explore patterns of spatial association among the selected tree species. The statistical significance of these indices was tested at $\alpha=0.05$ by comparison with corresponding values obtained from 5967 randomizations. All spatial statistics were performed using SADIE software (http://www.rothamsted.ac.uk/pie/sadie).

\section{Plant and soil sampling}

Based on the results of our vegetation study, we chose four dominant understory woody species and examined their $\mathrm{N}$ use traits: Leucosceptrum stellipilum (Miq.) Kitam. et Murata (Lamiaceae), Hydrangea hirta (Thunb.) Siebold (Saxifragaceae), Pieris japonica (Thunb.) D. Don (Ericaceae), and Lindera triloba (Sieb. et Zucc.) Blume (Lauraceae). Samples were collected five times during the 1998 growing season between late April, when leaves had not fully developed, and early October, immediately before deciduous leaves were shed. On each sampling date, the leaves of 5 plants of L. stellipilum, H. hirta, and P. japonica were collected from across their respective distributional ranges; 10 plants of $L$. triloba were sampled because this species had a wider distribution than the others. To ensure temporal independence in the data, individual plants were never sampled more than once. Soil samples were collected simultaneously with leaves. Triplicate mineral soil samples $(0-5 \mathrm{~cm}$ layer) were collected with a $100-\mathrm{cc}$ corer $(5-\mathrm{cm}$ depth) from areas within a 30$\mathrm{cm}$ radius of the tree trunks. Samples collected within this radius should be considered the rhizosphere soil of the target sample plants because a large proportion of fine roots occurs in the upper $10 \mathrm{~cm}$ of soil at the study site (Kasuya and Shimada 1996). Preliminary observations revealed no significant changes in soil inorganic $\mathrm{N}$ pool size within a $30-\mathrm{cm}$ radius of individual trees (data not shown).

\section{Plant analysis}

In vivo NRA was measured with a modified version of Jaworski's method (Jaworski 1971; Koyama and Tokuchi 2003). Leaf samples were collected between 10:00 and 14:00 on sunny days, and kept at $4{ }^{\circ} \mathrm{C}$ until analysis. The storage times before laboratory analysis ranged from $c a .3$ to $4 \mathrm{~h}$, so storage effects were similar across samples; changes in NRA are very slow after the initial decline during the first $30 \mathrm{~min}$ (Högberg et al. 1986). Petioles and midribs were removed, and ca. $100 \mathrm{mg}$ (fresh weight) of leaf laminae were cut into $2.5-\mathrm{mm}$-diameter disks or approximately $4-\mathrm{mm}^{2}$ segments 
and transferred to test tubes. Incubation buffer $(5 \mathrm{ml})$ was added, and the tubes were vacuum infiltrated. The composition of the incubation buffer was $0.1 \mathrm{~mol} \mathrm{~L}^{-1} \mathrm{KNO}_{3}, 0.1 \mathrm{~mol} \mathrm{~L}^{-1} \mathrm{KH}_{2} \mathrm{PO}_{4}$, and 3.0\% 1-propanol. $\mathrm{pH}$ was adjusted to $c a .7 .5$ using a $\mathrm{NaOH}$ solution. The samples were incubated for $1 \mathrm{~h}$ at $30^{\circ} \mathrm{C}$ in the dark. Enzyme activity was stopped by placing sample vials in hot water $\left(80^{\circ} \mathrm{C}\right)$. The concentration of $\mathrm{NO}_{2}^{-}-\mathrm{N}$ in the incubation buffer was measured colorimetrically by diazotization (Keeney and Nelson 1982). The effect of plant pigments was compensated for by measurement of controls lacking N-naphtylethylene diamine dihydrochloride (Gebauer et al. 1998). A fraction of each leaf sample was oven-dried at $105^{\circ} \mathrm{C}$ and then weighed to calculate activity per unit dry weight.

The remaining leaves were dried at $40^{\circ} \mathrm{C}$ and ground in a sample mill (CMT, Ltd., TI-100, Tokyo, Japan). About $100 \mathrm{mg}$ of ground samples were extracted with $10 \mathrm{ml}$ of deionized water for $1 \mathrm{~h}$ at $45^{\circ} \mathrm{C}$. The extract was filtered and the concentration of $\mathrm{NO}_{3}{ }^{-} \mathrm{N}$ in the extract was analyzed using HPLC within about $48 \mathrm{~h}$ to avoid the transformation of nitrate in the extract. Nitrate was separated on an anion exchange column (Shim-pack IC-A1 SHIMADZU, Kyoto, Japan) connected to a guard column (IC-GA1 SHIMADZU, Kyoto, Japan); electrical conductivity was measured with a conductivity detector (CDD-6A SHIMADZU, Kyoto, Japan). A potassium hydrogen phthalate solution was used as the mobile phase. The concentrations of $\mathrm{N}$ in ground samples were analyzed using an NC analyzer (NC-900; SUMIKA, Osaka, Japan).

\section{Soil analysis}

Soil samples were sieved through a 2-mm mesh, and roots were removed by hand. A 5-g sample was extracted with $50 \mathrm{ml}$ of $2 \mathrm{M} \mathrm{KCl}$ and filtered. The $\mathrm{NH}_{4}{ }^{+}-\mathrm{N}$ concentrations in the soil extracts were determined using the indophenol blue method (Keeney \& Nelson, 1982). The $\mathrm{NO}_{3}{ }^{-}-\mathrm{N}$ in the extracts was determined by diazotization after reduction to $\mathrm{NO}_{2}^{-}-\mathrm{N}$ with zinc powder (Keeney \& Nelson, 1982). Total soil inorganic $\mathrm{N}\left(\mathrm{NH}_{4}{ }^{+}-\mathrm{N}+\mathrm{NO}_{3}{ }^{-}-\mathrm{N}\right)$ and soil $\mathrm{NO}_{3}{ }^{-}-\mathrm{N}$ pool size were calculated as $\mathrm{N}$ mass per unit area $(5 \mathrm{~cm}$ depth).

\section{Statistical analysis}

One-way ANOVA was conducted to detect differences among sampling dates in leaf NRA, $\mathrm{NO}_{3}^{-}-\mathrm{N}$ concentration, $\mathrm{N}$ concentration, soil inorganic $\mathrm{N}$ pool size, and soil $\mathrm{NO}_{3}^{-}-\mathrm{N}$ pool size. Pearson's correlation coefficients were calculated between soil $\mathrm{N}$ traits and leaf traits. All statistical analyses were conducted in SAS JMP IN (ver. 5.1.1; SAS Institute, Cary, NC, USA).

\section{RESULTS}

\section{Vegetation study}

In total, we found 1518 tree trunks belonging to 54 species in plot A (Appendix 1). The numbers of both species and trunks increased slightly with increasing distance upward from the base 
of the slope; the trend was more marked on the upper slope than in the first $30 \mathrm{~m}$ from the base [Fig. 1(i)]. There were four dominant species, which accounted for $67.9 \%$ of all trunks, with specific distribution patterns [Fig. 1(j)]. Leucosceptrum stellipilum was distributed on the lower slope $(<27 \mathrm{~m}$ from the base). The mid slope (30-87 $\mathrm{m}$ from the base) was dominated by H. hirta, which was especially localized in the section 36-66 m from the base. The upper part of the slope ( $>51 \mathrm{~m}$ from the base) was dominated by Ericaceae species, such as P. japonica. Another dominant species, L. triloba, was distributed across the entire slope.

There were 2382 trunks of 53 tree species in plot B. Three of the dominant species in plot A were also dominant in plot B, i.e., H. hirta, P. japonica, and L. triloba with 434, 602, and 185 stems, respectively. Hydrangea hirta was concentrated in a zone $<66-69 \mathrm{~m}$ from the base of the slope; $P$. japonica was dominant in a zone $>63-66 \mathrm{~m}$ from the base of the slope [Fig. 2(a),(b)]. L. triloba occurred across the entire plot [Fig. 2(c)].

The spatial distributions of $H$. hirta and $P$. japonica were significantly aggregated $(\mathrm{P}<0.05)$ with extreme patches and gaps $(\mathrm{P}<0.05)$, while that of $L$. triloba was random and without patches or gaps (Table 1). Spatial association pattern analysis demonstrated that the distributions of H. hirta and $P$. japonica and of $H$. hirta and L. triloba were significantly dissociated $(\mathrm{P}<0.05)$; distributions of $P$. japonica and L. triloba were independent (Table 2).

\section{Seasonal changes in plant $\mathbf{N}$ use traits and soil $\mathbf{N}$ pool size}

Leaf $\mathrm{N}$ concentrations tracked a similar seasonal pattern in all four species [Fig. 3(a), Appendix 2]. Leaf $\mathrm{N}$ concentrations were highest at the beginning of the growing season $(\mathrm{p}<0.01)$, declined markedly during the first month, and remained stable thereafter.

Seasonal changes in leaf $\mathrm{NO}_{3}^{-}-\mathrm{N}$ concentrations differed among species [Fig. 3(b), Appendix 2]. There were no significant differences in leaf $\mathrm{NO}_{3}{ }^{-} \mathrm{N}$ concentrations among sampling dates for $L$. stellipilum $(\mathrm{p}=0.12)$ or $H$. hirta $(\mathrm{p}=0.21)$. The seasonal patterns of leaf $\mathrm{NO}_{3}{ }^{-}-\mathrm{N}$ concentrations in $L$. triloba and $P$. japonica were rather similar to those of leaf $\mathrm{N}$ concentrations, which declined during the first month and remained stable thereafter. Leaf $\mathrm{NO}_{3}{ }^{-} \mathrm{N}$ concentrations in P. japonica were very low throughout the sampling period.

Leaf NRA did not vary significantly across sampling days, except in L. stellipilum $(\mathrm{p}<0.01)$, for which NRA was maximal on the 2nd sampling day [Fig. 3(c), Appendix 2]. Leaf NRA was hardly detected in $P$. japonica.

Inorganic $\mathrm{N}$ pool sizes in soils associated with L. stellipilum and H. hirta tracked similar patterns; they peaked on the 4th sampling day [Fig. 3(d)(e), Appendix 2]. Inorganic N pool size was highest on the 3rd and 4th sampling days in soils associated with L. triloba. Seasonal changes in the inorganic $\mathrm{N}$ pool size in soils associated with $P$. japonica differed from those in soils associated with other species; the lowest pool size in soils associated with P. japonica occurred on the 4th sampling 
day.

$\mathrm{NO}_{3}{ }^{-}-\mathrm{N}$ pool sizes tracked the temporal pattern seen in soil inorganic $\mathrm{N}$ associated with understory plant species other than $P$. japonica [Fig. 3(e), Appendix 2]. The soil $\mathrm{NO}_{3}{ }^{-}-\mathrm{N}$ pool size associated with P. japonica was an order of magnitude smaller than the pool sizes associated with other species. The pool size associated with $P$. japonica peaked on the last sampling day. Soil $\mathrm{NO}_{3}{ }^{-} \mathrm{N}$ pool sizes associated with the other three species peaked on the 4th sampling day, in late summer. However, in soil associated with L. triloba, differences in the pool sizes between the $3 \mathrm{rd}$ and 4 th sampling days were not significant $(\mathrm{p} \geq 0.05)$.

\section{Relationships between plant $\mathrm{N}$-use traits and soil $\mathbf{N}$ pool sizes}

With few exceptions, neither soil $\mathrm{NO}_{3}{ }^{-}-\mathrm{N}$ pool size nor soil inorganic $\mathrm{N}$ pool size was significantly correlated with leaf $\mathrm{N}$ concentration or leaf $\mathrm{NO}_{3}{ }^{-} \mathrm{N}$ concentration in any of the species across the sampling period ( $\mathrm{p} \geq 0.05$; Table 3 ). There were significant positive correlations between soil $\mathrm{NO}_{3}{ }^{-}-\mathrm{N}$ pool size and leaf NRA for $L$. triloba throughout the sampling period $(\mathrm{p}<0.05)$, except on the 1 st sampling day $(\mathrm{p}=0.56)$. For L. stellipilum and H. hirta, there were significant positive correlations between soil $\mathrm{NO}_{3}{ }^{-}-\mathrm{N}$ pool sizes and leaf NRA only on the 1st sampling day $(\mathrm{p}<0.05)$. With one exception, correlation coefficients between soil inorganic N pool sizes and leaf NRA were not significant across the sampling period for any of the species $(\mathrm{p} \geq 0.05)$. There was a significant correlation for L. stellipilum on the 1 st sampling day $(\mathrm{p}<0.01)$.

\section{DISCUSSION}

\section{Correspondence between plant species' distributions and soil $\mathbf{N}$ conditions}

The dominant understory plants in the study plots had species-specific distribution patterns along the slope [Figs. 1(j), 2(a)-(c), Tables 1, 2]. Spatial analysis by distance indices for the mid slope (plot B) demonstrated that the spatial distributions of dominant species other than L. triloba were likely reflections of environmental conditions on the gradient.

As in the classification in the Materials and Methods section, both net and gross soil nitrification rates were high on the lower slope; net nitrification rates were high but gross nitrification rates were low on the mid slope; and both net and gross nitrification rates were low on the upper slope [Figs. 1(g)-(h); Tokuchi et al. 2000, Hirobe et al. 1998]. Interestingly, the boundaries of these three categories corresponded to the points on the slope where the dominant understory species changed [Figs. 1(j), 2(a)-(b), 4]. Furthermore, additional environmental factors, such as microtopography, light conditions, soil $\mathrm{pH}$, and moisture conditions, also changed along the slope, but less dramatically than the soil nitrification rate (Fig. 1). Thus, there was correspondence only between vegetation distribution ranges and soil nitrification rates. In short, soil on the slope was classifiable into three different categories by nitrification rate, and the spatial distribution of these categories corresponded to the 
spatial distribution of the dominant understory species (Figs. 1,2).

\section{Species difference in plant $\mathrm{NO}_{3}^{-}-\mathrm{N}$ use}

Using NRA analysis, we classified the four study species into three categories based on $\mathrm{NO}_{3}{ }^{-}$$\mathrm{N}$ use: species that lack the capacity to assimilate $\mathrm{NO}_{3}^{-}-\mathrm{N}$, species able to assimilate $\mathrm{NO}_{3}^{-}-\mathrm{N}$, and species that accumulate $\mathrm{NO}_{3}{ }^{-}-\mathrm{N}$ in addition to assimilating $\mathrm{NO}_{3}{ }^{-}-\mathrm{N}$ immediately.

Many members of the Ericaceae have extremely low NRA and are presumably unable to use $\mathrm{NO}_{3}{ }^{-} \mathrm{N}$ as a N source (Gebauer et al. 1988; Högbom and Ohlson 1991; Nadelhoffer et al. 1996). In our study, the ericaceous species Pieris japonica had very little or no leaf NRA throughout the growing period [Fig. 3(c)]. Furthermore, Koyama and Tokuchi (2003) were unable to detect NRA in either leaves or roots of $P$. japonica, even when considerable concentrations of $\mathrm{NO}_{3}{ }^{-}-\mathrm{N}$ were artificially supplied. Thus, $P$. japonica has essentially no capacity to use $\mathrm{NO}_{3}{ }^{-} \mathrm{N}$ as a $\mathrm{N}$ source.

The family Lamiaceae includes several nitrophilous species that preferentially use $\mathrm{NO}_{3}{ }^{-}-\mathrm{N}$ as a $\mathrm{N}$ source (Gebauer et al. 1988). The lamiaceous species at our study site, L. stellipilum, ranks among them because of its high NRA [Fig. 3(c)]. Furthermore, leaf $\mathrm{NO}_{3}{ }^{-}-\mathrm{N}$ concentrations were much higher in L. stellipilum than in the other species [Fig. 3(b)]. At its maximum concentration, $\mathrm{NO}_{3}{ }^{-}-\mathrm{N}$ amounted to $c a .40 \%$ of total leaf $\mathrm{N}$. Rehder (1982) defined nitrate accumulators as species that accumulate $\mathrm{NO}_{3}{ }^{-}$ $-\mathrm{N}$ above a fixed value (for example, $0.05 \%$ of dry weight or $1 \%$ of total $\mathrm{N}$ ); these amounts of $\mathrm{NO}_{3}{ }^{-}-\mathrm{N}$ are detected in leaf laminae, which are believed to have lower $\mathrm{NO}_{3}{ }^{-} \mathrm{N}$ contents than roots, stems, or leaf stalks (cf. Gebauer et al. 1984, Gebauer and Schulze 1997); and such concentrations of $\mathrm{NO}_{3}{ }^{-} \mathrm{N}$ are measured not only at the early stage of development but also at the end of the growing season and with the decay of leaves. Leucosceptrum stellipilum fits the definition of a nitrate accumulator, although we have not as yet measured $\mathrm{NO}_{3}{ }^{-}-\mathrm{N}$ concentration in decayed leaves. $\mathrm{NO}_{3}{ }^{-}-\mathrm{N}$ accumulation is regulated by the balance between $\mathrm{NO}_{3}{ }^{-}-\mathrm{N}$ uptake and $\mathrm{NO}_{3}{ }^{-}-\mathrm{N}$ reduction (Luo et al. 2006). The very high $\mathrm{NO}_{3}{ }^{-}-\mathrm{N}$ concentrations and $\mathrm{NO}_{3}^{-}-\mathrm{N}$ reduction rates in L. stellipilum leaves indicate that $\mathrm{NO}_{3}^{-}-\mathrm{N}$ uptake was also high [Fig. 3(b),(c)]. In earlier $\mathrm{N}$ starvation experiments, $\mathrm{NO}_{3}{ }^{-} \mathrm{N}$ was shown to accumulate in plant tissues, and it may be mobilized and utilized (Melzer et al. 1984; Chapin et al. 1990). Even if $\mathrm{NO}_{3}{ }^{-}-\mathrm{N}$ stored in the cell vacuole is not utilized, the ion may act as an osmotic solute (Martinoia et al. 1981; Smirnoff and Stewart 1985; Tischner and Kaiser 2007).

\section{Seasonal changes in plant $\mathbf{N}$ use}

Soil $\mathrm{NO}_{3}{ }^{-}-\mathrm{N}$ availability is frequently cited as a factor that regulates temporal changes in plant NRA. For example, temporal NRA changes in the shoots of Deschampsia flexuosa (Troelstra et al. 1995 ) and in Picea rubens needles (Tjoelker et al. 1992) correspond to changes in soil $\mathrm{NO}_{3}{ }^{-} \mathrm{-N}$ availability. However, we found almost no significant changes in leaf NRA [Fig. 3(c), Appendix 2], while $\mathrm{NO}_{3}{ }^{-} \mathrm{N}$ pool sizes in soil associated with the study species other than $P$. japonica peaked on the 
4th sampling day in late summer [Fig. 3(e)]. Thus, temporal changes in the soil $\mathrm{NO}_{3}{ }^{-}-\mathrm{N}$ pool size influenced neither $\mathrm{NO}_{3}{ }^{-}-\mathrm{N}$ assimilation nor $\mathrm{NO}_{3}{ }^{-}-\mathrm{N}$ uptake in any of the dominant understory species.

In a variety of species, leaf NRA is highest in the relatively early stages of leaf growth (Gebauer et al. 1987; Högberg et al. 1986, 1992; Ohlson and Högbom 1993; Pearson and Ji 1994; Stadler and Gebauer 1992; Troelstra et al. 1995). The peak in leaf NRA in selected woody species occurs concurrently with the peak in the leaf-expansion rate at the midpoint of leaf opening (Koyama et al. 2008). We started sampling in late April, when leaves appeared to be not fully developed, and the decline in leaf $\mathrm{N}$ concentration in the first month demonstrated that leaves were not fully expanded on the 1st sampling day [Fig. 3(a)]. Therefore, it is very likely that the high $\mathrm{N}$ demand during leaf expansion stimulates NRA. Nevertheless, leaf NRA did not change significantly with season except in L. stellipilum, and peak NRA in this species did not occur during the leaf expansion period [Fig. 3(c), Appendix 2]. The increase and decrease in NRA during the leaf expansion period occurs rapidly (Koyama et al. 2008), and it is therefore possible that the frequency of our observations was inadequate to resolve the NRA peak during the leaf expansion period.

\section{Influence of soil $\mathrm{NO}_{3}^{-}-\mathrm{N}$ pool size on plant $\mathrm{NO}_{3}{ }^{-} \mathrm{N}$ use}

Since the enzyme NR is substrate inducible (Tischner and Kaiser 2007), soil $\mathrm{NO}_{3}{ }^{-}-\mathrm{N}$ availability is considered a factor in regulating plant NRA (Högberg et al. 1986; Koyama and Tokuchi 2003; Melzer et al. 1984). However, we found almost no correspondence between soil $\mathrm{NO}_{3}{ }^{-}-\mathrm{N}$ pool sizes and leaf NRA, except in L. triloba, which was distributed across the entire slope gradient irrespective of soil nitrification rate [Figs. 1, 2, Table 3]. The relationship between L. triloba NRA and soil $\mathrm{NO}_{3}{ }^{-}-\mathrm{N}$ availability was different from those of other species. Most of soils associated with $L$. stellipilum and $H$. hirta had relatively large $\mathrm{NO}_{3}{ }^{-}-\mathrm{N}$ pool sizes $\left(>30 \mathrm{mg} \mathrm{N} \mathrm{m}^{-2}\right)$, and all soils associated with $P$. japonica had $\mathrm{NO}_{3}{ }^{-}-\mathrm{N}$ pool sizes $<30 \mathrm{mg} \mathrm{N} \mathrm{m}^{-2}$. On the other hand, nearly $50 \%$ of soils associated with $L$. triloba had $\mathrm{NO}_{3}{ }^{-} \mathrm{-}$ pool sizes $<30 \mathrm{mg} \mathrm{N} \mathrm{m}^{-2}$, and the other of soils had $\mathrm{NO}_{3}{ }^{-} \mathrm{N}$ pool sizes $>30 \mathrm{mg} \mathrm{N} \mathrm{m}^{-2}$. Hence, the leaf NRA of species growing where the $\mathrm{NO}_{3}^{-}-\mathrm{N}$ availability spectrum was limited (either $\mathrm{NO}_{3}^{-}-\mathrm{N}$ rich or $\mathrm{NO}_{3}^{-}-\mathrm{N}$ poor) did not respond to changes in $\mathrm{NO}_{3}^{-}-\mathrm{N}$ availability. In contrast, the leaf NRA of the species growing across a wide range of $\mathrm{NO}_{3}-\mathrm{N}$ availability responded to changes in $\mathrm{NO}_{3}{ }^{-} \mathrm{N}$ availability. Therefore, species' responsiveness to changes in $\mathrm{NO}_{3}{ }^{-}-\mathrm{N}$ availability are a factor that regulates plant distributions.

Another possible mechanism contributing to the lack of a significant correlation between soil $\mathrm{NO}_{3}^{-}-\mathrm{N}$ pool size and leaf NRA may be partitioning of $\mathrm{NO}_{3}^{-}-\mathrm{N}$ assimilation between leaves and roots. $\mathrm{NO}_{3}{ }^{-}-\mathrm{N}$ fertilization increases NRA in the roots of seedlings and cuttings of L. triloba and H. hirta, but not in the leaves (Koyama and Tokuchi 2003). Thus in our investigation, the soil $\mathrm{NO}_{3}{ }^{-}-\mathrm{N}$ pool size may have regulated root NRA but not leaf NRA. However, scaling up from a small experimental configuration, such as that in Koyama and Tokuchi (2003), to our large-scale field study is difficult. In 
the fertilization experiment, NRA was very low in L. triloba leaves, irrespective of soil $\mathrm{NO}_{3}{ }^{-} \mathrm{N}$ pool size, whereas we detected considerable NRA in the leaves of L. triloba under natural conditions. It is possible that such differences are caused by differences in tree age between studies, or in environmental conditions, such as light, moisture, or temperature. Thus, we are presently unable to make unequivocal statements about the potential variability in root NRA when the soil $\mathrm{NO}_{3}{ }^{-}-\mathrm{N}$ pool size changes under natural conditions.

Even though soil $\mathrm{NO}_{3}{ }^{-}-\mathrm{N}$ availability decreased with distance from the base of the slope and this decrease influenced leaf $\mathrm{NO}_{3}{ }^{-} \mathrm{N}$ assimilation in L. triloba, the leaf $\mathrm{N}$ content in this species did not vary in concert with changing soil $\mathrm{NO}_{3}{ }^{-} \mathrm{N}$ availability (Table 3). Hence, L. triloba may not depend entirely on $\mathrm{NO}_{3}{ }^{-} \mathrm{N}$, but may also be able to use other species of $\mathrm{N}$, i.e., $\mathrm{NH}_{4}{ }^{+}-\mathrm{N}$ and organic $\mathrm{N}$. Koba et al. (2003) observed that NRA and the natural abundance of ${ }^{15} \mathrm{~N}\left(\delta^{15} \mathrm{~N}\right)$ in leaves of L. triloba were significantly negatively correlated at a $\mathrm{NO}_{3}{ }^{-}-\mathrm{N}$-rich site, but not at a $\mathrm{NO}_{3}{ }^{-}-\mathrm{N}-$ poor site. They attributed the negative correlation in this species to a high dependence on $\mathrm{NO}_{3}{ }^{-}-\mathrm{N}$ in $\mathrm{NO}_{3}{ }^{-} \mathrm{N}$-rich soil (cf. Miller and Bowman 2002). The corollary is that L. triloba growing in $\mathrm{NO}_{3}^{-}-\mathrm{N}$-poor soils depends on $\mathrm{N}$ sources other than $\mathrm{NO}_{3}^{-}-\mathrm{N}$, which is consistent with the results of the present study, suggesting that this species changes major $\mathrm{N}$ sources according to the form and amount of available $\mathrm{N}$.

Fujimaki et al. (2001) showed that the arbuscular mycorrhizal colonization of L. triloba roots increases with distance from the base of the slope at our study site, but that this is not the case for $L$. stellipilum and $H$. hirta. Both decomposition processes, i.e., the release of mobile $\mathrm{N}$ to the rhizosphere, and capture of the less mobile amino acids or $\mathrm{NH}_{4}{ }^{+} \mathrm{N}$ by plants may be enhanced by arbuscular mycorrhizal colonization (Read and Perez-Moreno 2003). Therefore, it is possible that in our study $L$. triloba depended more on $\mathrm{N}$ acquired by mycorrhizae under $\mathrm{NO}_{3}{ }^{-}-\mathrm{N}$-poor conditions than under $\mathrm{NO}_{3}^{-}-$ N-rich conditions.

Furthermore, the thickness of the organic layer increased with distance from the base of the slope [Fig. 1(d); Hobara and Tokuchi 1998], suggesting a slower decomposition rate on the upper slope. This is consistent with the proposition that L. triloba under $\mathrm{NO}_{3}{ }^{-}-\mathrm{N}$-poor conditions on the upper slope acquires organic $\mathrm{N}$ through mycorrhizal activities that facilitate plant acquisition of organic N. Therefore, mycorrhizal colonization may explain, at least in part, the process by which the leaf $\mathrm{N}$ concentrations of $L$. triloba come to be similar across a range of soil $\mathrm{NO}_{3}{ }^{-}-\mathrm{N}$ availabilities.

Mycorrhizal colonization very likely contributes to $\mathrm{N}$ acquisition in other species. Pieris japonica is symbiotic with ericoid mycorrhizae in the study site (Fujimaki et al. 2001). Ericoid mycorrhizal colonization facilitates a direct pathway of organic $\mathrm{N}$ to the plant symbiont (Read and Perez-Moreno 2003). The occurrence of P. japonica was highest on the upper slope at our study site, where a thick organic layer had accumulated [Figs. 1(d), (j)] and roots likely took up organic $\mathrm{N}$ via ericoid mycorrhizae. 


\section{Possible counter-effect of plants on soil $\mathbf{N}$ transformation}

Soil $\mathrm{N}$ influences plant $\mathrm{N}$ use; conversely, dominant plant species affect $\mathrm{N}$ cycling in soil systems. Studies of soils beneath different tree species indicate that plant species might influence soil N dynamics (Bengtson et al. 2006; Chen and Stark 2000; Zeller et al. 2007). Species' capacities for retaining $\mathrm{N}$ in ecosystems mirror differences in their preferences for diverse forms of $\mathrm{N}$ (Templer and Dawson 2004; Templer et al. 2005). Conversely, the quality of organic matter, i.e., litter quality from different plant species, has a considerable influence on soil $\mathrm{N}$ transformation in several ecosystems (Ferrari 1999). Laughlin (2011) demonstrated in a ponderosa pine forest that soil nitrification potential was more strongly linked to the leaf traits of understory species than to functional diversity. Giesler et al. (1998) suggested that the correspondence between vegetation and soil on a scale of tens of meters mirrors feedback effects of plants on soil processes. Correspondence between the distribution of understory species and soil $\mathrm{N}$ forms may also reflect feedback effects of plants on the soil at our study site.

Hirobe et al. (1998) concluded that the changes in the net nitrification rate along the slope at our study site is regulated by the amount of readily decomposable organic matter, soil water content, and $\mathrm{pH}$. The tree layer is a monoculture of even-aged Japanese cedar, which likely provides litter that contributes most of the soil organic matter in this study site. The quality and quantity of organic matter supplied by overstory species is unlikely to have changed dramatically along the slope gradient. In contrast, there is considerable variation in the dominant understory species along the gradient, and the distribution of each corresponds to the distribution of different soil types [Figs. 1(g)(h)(j), 2]. Each species likely contributes organic matter in a species-specific manner, which may partly account for differences in soil $\mathrm{N}$ transformation, especially nitrification, along the slope. Information on the litter quality of understory species is not available, but the $\mathrm{N}$ concentrations of living leaves continued different markedly among the dominant understory species to the late growing season [Fig. 3(a)]. Since leaf $\mathrm{C}$ concentration are almost constant, the $\mathrm{C} / \mathrm{N}$ ratios of living leaves differed among the species (data not shown); consequently, the $\mathrm{C} / \mathrm{N}$ ratio of leaf litter must vary. Accordingly, it is very likely that the amount of readily decomposable organic matter in soil differs with the dominant plant species growing in the soil. The distinct change in dominant understory species along the slope probably contributes to the formation of spatially differentiated soil types with different $\mathrm{N}$ transformation properties. However, the ratio of understory biomass to total biomass is small, and further investigation is required to accurately estimate the contribution of the understory to soil properties and $\mathrm{N}$ cycling in this ecosystem.

\section{Relationship between understory plants and soil at the study site}

Read and Perez-Moreno (2003) described changes in vegetation and major soil N species across latitudes and altitudes on a global scale; types of mycorrhizae corresponded to changes in 
vegetation. Based on the relationships among plants, soil N, and mycorrhizal type, and on the function of mycorrhizal colonization in plant $\mathrm{N}$ acquisition, they proposed that mycorrhizal fungi significantly contribute to ecosystem N cycling in ways that are distinctive by latitude and altitude (Read and PerezMoreno 2003). They further proposed that this perspective is also applicable at more local scales (Read and Perez-Moreno 2003). We believe it probable that similar relationships among vegetation, soil $\mathrm{N}$ form, and mycorrhizal type have developed along the slope at our study site.

Based on net nitrification rates, Koba et al. (2003) divided our study area into two sites, the lower and the upper. They demonstrated differences in $\delta^{15} \mathrm{~N}$ in plants and soil between sites, and attributed these to the relative importance of soil nitrification and $\mathrm{NH}_{4}{ }^{+}-\mathrm{N}$ immobilization (Koba et al. 2003). However, their lower site is divisible into two smaller sections based on dominant understory species and gross soil $\mathrm{N}$ transformations. By comparing our work with previous studies at the same study site, we summarize the relationships among position on the slope, soil $\mathrm{NO}_{3}{ }^{-}-\mathrm{N}$ availability, dominant understory species identity, and plant species physiological characteristics (Table 4). Based on this comparison among soil $\mathrm{N}$ availability, dominant understory species identity, and plant species physiological characteristics, the physiological plasticity of species' response to changes in $\mathrm{NO}_{3}{ }^{-}-\mathrm{N}$ availability regulates plant distribution ranges in accordance with soil $\mathrm{NO}_{3}{ }^{-}-\mathrm{N}$ availability at the study site.

Kronzucker et al. (1997) suggested that a species with reduced capacity to use $\mathrm{NO}_{3}{ }^{-}-\mathrm{N}$ presented a critical impediment to seedling establishment on disturbed site where $\mathrm{NO}_{3}{ }^{-}-\mathrm{N}$ availability was high. Similarly, a species that certainly lacks the capacity to use $\mathrm{NO}_{3}{ }^{-} \mathrm{N}$ in the study site, $P$. japonica, is under disadvantage on $\mathrm{NO}_{3}^{-}-\mathrm{N}$ rich soil. Therefore, it is highly possible that $P$. japonica has tolerance to the toxicity of $\mathrm{NH}_{4}{ }^{+}-\mathrm{N}$ and preference to $\mathrm{NH}_{4}{ }^{+}-\mathrm{N}$ as frequently found in ericaceous species (e.g. Nordin et al. 2001); consequently, it become dominant on $\mathrm{NH}_{4}{ }^{+}-\mathrm{N}$ dominated soil as suggested with late-successional species that has high tolerance to $\mathrm{NH}_{4}{ }^{+}-\mathrm{N}$ toxicity and high efficiency of $\mathrm{NH}_{4}{ }^{+}-\mathrm{N}$ transport (Kronzucker et al. 2003).

Combining the results of our field investigation and an earlier fertilization experiment suggesting that $H$. hirta is more responsive to changes in $\mathrm{NO}_{3}{ }^{-}-\mathrm{N}$ availability and more dependent on $\mathrm{NO}_{3}{ }^{-} \mathrm{N}$ than L. triloba (Koyama and Tokuchi 2003), we can summarize the relationship between a species' physiological traits and its distribution as follows. A species highly dependent on $\mathrm{NO}_{3}{ }^{-} \mathrm{N}$ as a $\mathrm{N}$ source and sensitive to $\mathrm{NO}_{3}^{-}-\mathrm{N}$ deficiency, namely $H$. hirta, has a narrow distribution range. A species less dependent on $\mathrm{NO}_{3}{ }^{-}-\mathrm{N}$ as a $\mathrm{N}$ source and insensitive to changes in $\mathrm{NO}_{3}{ }^{-}-\mathrm{N}$ availability, i.e., L. triloba, has a larger distribution range under natural conditions. Therefore, we conclude that physiological traits and the plasticity of plant species in their use of $\mathrm{NO}_{3}^{-}-\mathrm{N}$ are among the factors that regulate species' distribution ranges; thus, soil $\mathrm{NO}_{3}{ }^{-} \mathrm{N}$ availability is an environmental factor that influences plant distribution.

However, the spatial differentiation of L. stellipilum and $H$. hirta cannot be explained by 
differences in their $\mathrm{NO}_{3}^{-}-\mathrm{N}$ use. In terms of net nitrification rates, both the lower slope dominated by $L$. stellipilum and the mid slope dominated by $H$. hirta have high $\mathrm{NO}_{3}{ }^{-} \mathrm{-N}$ availability [Figs. 1(h), 4]. However, gross nitrification rates are markedly different between the two slope sections [Figs. 1(g), 4], suggesting a difference in soil microbial activity between the two portions of the slope. A possible explanation for the spatial differentiation of L. stellipilum and $H$. hirta is that there may be differences in their ability to compete with soil microbes for $\mathrm{NO}_{3}{ }^{-}-\mathrm{N}$ in the soils of the two slope sections.

\section{ACKNOWLEDGMENTS}

We would like to thank Drs. H. Takeda, N. Osawa and T. Osono for their valuable comments, and Mr. K. Yoshida for providing us with data on soil moisture conditions. We also thank Drs. Y. Asano and M. Katsuyama for their valuable advice on HPLC analysis, and Drs. S. Nanami and K. Ishimaru and other members of the Laboratory of Forest Ecology, Kyoto University for their help in fieldwork and laboratory analysis. 


\section{REFERENCE}

Al Gharbi A and Hipkin C R 1984 Studies on nitrate reductase in British angiosperms I. A comparison of nitrate reductase activity in ruderal, woodland-edge and woody species. New Phytol 97, 629-639.

Beevers L and Hageman R H 1969 Nitrate reduction in higher plants. Annu Rev Plant Physiol 20, 495-522.

Bengtson P, Falkengren-Grerup U and Bengtsson G 2006 Spatial distributions of plants and gross N transformation rates in a forest soil. J Ecol 94, 754-764.

Chapin III F S, Schulze E-D and Mooney H A 1990 The ecology and economics of storage in plants. Annu Rev Ecol Syst 21, 423-447.

Chen J and Stark J M 2000 Plant species effects and carbon and nitrogen cycling in a sagebrushcrested wheatgrass soil. Soil Biology \& Biochemistry 32, 47-57.

Enoki T 2003 Microtopography and distribution of canopy trees in a subtropical evergreen broadleaved forest in the northern part of Okinawa Island, Japan. Ecol Res 18, 103-113.

Enoki T, Kawaguchi H and Iwatsubo G 1997 Nutrient-uptake and nutrient-use efficiency of Pinus thunbergii Parl. along a topographical gradient of soil nutrient availability. Ecol Res 12, 191 199.

Ferrari J B 1999 Fine-scale patterns of leaf litterfall and nitrogen cycling in an old-growth forest. Can J For Res 29, 291-302.

Fujimaki R, Tateishi T, Kohzu A, Saito M and Tokuchi N 2001 Characterization of arbuscular mycorrhizal colonization of 4 plant species in a Japanese red cedar plantation. Soil Microorganisms 55, 121-128.

Gebauer G, Hahn G, Rodenkirchen H and Zuleger M 1998 Effects of acid irrigation and liming on nitrate reduction and nitrate content of Picea abies (L.) Karst. and Oxalis acetosella L. Plant Soil 199, 59-70.

Gebauer G, Melzer A and Rehder H 1984 Nitrate content and nitrate reductase activity in Rumex obtusifolius L.: 1. Differences in organs and diurnal changes. Oecologia 63, 136-142.

Gebauer G, Rehder H and Wollenweber B 1988 Nitrate, nitrate reduction and organic nitrogen in plants from different ecological and taxonomic groups of Central Europe. Oecologia 75, 371385.

Gebauer G, Schuhmacher M I, Krstic B, Rehder H and Ziegler H 1987 Biomass production and nitrate metabolism of Atriplex hortensis L. ( $\mathrm{C}_{3}$ plant) and Amaranthus retroflexus $\mathrm{L} .\left(\mathrm{C}_{4}\right.$ plant $)$ in cultures at different levels of nitrogen supply. Oecologia 72, 303-314.

Gebauer G and Schulze E-D 1997 Nitrate nutrition of Central European forest trees. In TreesContributions to Modern Tree Physiology. Eds. H Rennenberg, W Eschrich and H Ziegler. pp 273-291. Backhuys Publishers, Leiden, The Netherland. 
Giesler R, Högberg M and Högberg P 1998 Soil chemistry and plants in Fennoscandian boreal forest as exemplified by a local gradient. Ecology 79, 119-137.

Hipkin CR, Simpson DJ, Wainwright SJ and Salem MA 2004 Nitrification by plants that also fix nitrogen. Nature 430, 98-101.

Hirobe M, Tokuchi N and Iwatsubo G 1998 Spatial variability of soil nitrogen transformation patterns along a forest slope in a Cryptomeria japonica D. Don plantation. Euro J Soil Biol 34, 123-131.

Hirobe M, Tokuchi N and Iwatsubo G 2001 Spatial and vertical differences in in-situ soil nitrogen availability along a slope in a conifer plantation forest. Applied Forest Science 10, 19-25.

Hobara S and Tokuchi N 1998 Nutrient dynamics in the organic horizon of the Japanese cedar (Cryptomeria japonica). (in Japanese with English summary). Bulletin of the Kyoto University Forests 69, 1-13.

Högberg P, Granström A, Johansson T, Lundmark-Thelin A and Näsholm T 1986 Plant nitrate reductase activity as an indicator of availability of nitrate in forest soils. Can J For Res 16, 1165-1169.

Högberg P, Högbom L and Näsholm T 1992 Shoot nitrate reductase activities of field-layer species in different forest types. II. Seasonal variation and effects of temperature. Scand J For Res 7, 1-14.

Högbom L and Ohlson M 1991 Nitrate assimilation in coexisting vascular plants in mire and swamp forest habitats in Central Sweden. Oecologia 87, 495-499.

Jaworski E G 1971 Nitrate reductase assay in intact plant tissues. Biochem Biophys Res Commun 43, 1274-1279.

Kasuya N and Shimada H 1996 Change in the fine root biomass of Cryptomeria japonica in relation to position on a slope (in Japanese with English summary). Bulletin of Kyoto Prefectural University Forest 40, 1-12.

Keeney D R and Nelson D W 1982 Nitrogen - Inorganic forms. In Methods of Soil Analysis. Part 2. Eds. A L Page, R H Miller and D R Keeney. pp 643-698. ASA and SSSA, Madison, USA.

Koba K, Hirobe M, Koyama L, Kohzu A, Tokuchi N, Nadelhoffer K J, Wada E and Takeda H 2003 Natural ${ }^{15} \mathrm{~N}$ abundance of plants and soil $\mathrm{N}$ in a temperate coniferous forest. Ecosystems 6 , 457-469.

Koyama L and Tokuchi N 2003 Effects of $\mathrm{NO}_{3}{ }^{-}$availability on $\mathrm{NO}_{3}{ }^{-}$use in seedlings of three woody shrub species. Tree Physiol 23, 281-288.

Koyama L, Tokuchi N, Fukushima K, Terai M and Yamamoto Y 2008 Seasonal changes in nitrate use by three woody species: the importance of the leaf-expansion period. Trees 22, 851-859.

Kronzucker HJ, Siddiqi MY and Glass ADM 1997 Conifer root discrimination against soil nitrate and the ecology of forest succession. Nature 385, 59-61.

Kronzucker HJ, Siddiqi MY, Glass ADM and Britto DT 2003 Root ammonium transport efficiency as a determinant in forest colonization patterns: an hypothesis. Physiol Plant 117, 164-170. 
Laughlin DC 2011 Nitrification is linked to dominant leaf traits rather than functional diversity. J Ecol 99, 1091-1099.

Luo J, Sun S, Jia L, Chen W and Shen Q 2006 The mechanism of nitrate accumulation in pakchoi [Brassica campestris L. ssp. Chinensis (L.)]. Plant Soil 282, 291-300.

Martinoia E, Heck U and Wiemken A 1981 Vacuoles as storage compartments for nitrate in barley leaves. Nature 289, 292-294.

Melzer A, Gebauer G and Rehder H 1984 Nitrate content and nitrate reductase activity in Rumex obtusifolius: 2. Responses to nitrate starvation and nitrogen fertilization. Oecologia 63, 380385.

Miller A E and Bowman W D 2002 Variation in nitrogen-15 natural abundance and nitrogen uptake traits among co-occurring alpine species: do species partition by nitrogen form? Oecologia 130, 609-616.

Min X, Siddiqi MY, Guy RD, Glass ADM and Kronzucker HJ 1998 Induction of nitrate uptake and nitrate reductase activity in trembling aspen and lodgepole pine. Plant, Cell Environ 21, 10391046.

Nadelhoffer K, Shaver G, Fry B, Giblin A, Johnson L and McKane R $1996{ }^{15} \mathrm{~N}$ natural abundances and $\mathrm{N}$ use by tundra plants. Oecologia 107, 386-394.

Nordin A, Högberg P and Näsholm T 2001 Soil nitrogen form and plant nitrogen uptake along a boreal forest productivity gradient. Oecologia 129, 125-132.

Ohlson M and Högbom L 1993 Species-specific dynamics in nitrate reductase activity in coexisting swamp forest plants. J Ecol 81, 739-744.

Ohwi J and Kitagawa M 1992 New Flora of Japan (in Japanese). Shibundo, Tokyo, Japan.

Pearson J and Ji Y M 1994 Seasonal variation of leaf glutamine synthetase isoforms in temperate deciduous trees strongly suggests different functions for the enzymes. Plant Cell Environ 17, 1331-1337.

Perry JN 1995 Spatial Analysis by Distance Indices. J Anim Ecol 64, 303-314.

Read D J and Perez-Moreno J 2003 Mycorrhizas and nutrient cycling in ecosystems - a journey towards relevance? New Phytol 157, 475-492.

Rehder H 1982 Nitrogen relations of ruderal communities (Rumicion alpini) in the Northern Calcareous Alps. Oecologia 55, 120-129.

Sakai A and Ohsawa M 1993 Vegetation pattern and microtopography on a landslide scar of Mt. Kiyosumi, central Japan. Ecol Res 8, 47-56.

Sakai A and Ohsawa M 1994 Topographical pattern of the forest vegetation on a river basin in a warm-temperate hilly region, central Japan. Ecol Res 9, 269-280.

Small C J and McCarthy B C 2005 Relationship of understory diversity to soil nitrogen, topographic variation, and stand age in an eastern oak forest, USA. For Ecol Manage 217, 229-243. 
Smirnoff N and Stewart G R 1985 Nitrate assimilation and translocation by higher plants:

Comparative physiology and ecological consequences. Physiol Plant 64, 133-140.

Smirnoff N, Todd P and Stewart G R 1984 The occurrence of nitrate reduction in the leaves of woody plants. Ann Bot 54, 363-374.

Stadler J and Gebauer G 1992 Nitrate reduction and nitrate content in ash trees (Fraxinus excelsior L.): distribution between compartments, site comparison and seasonal variation. Trees 6, 236240.

Tateno R and Takeda H 2003 Forest structure and tree species distribution in relation to topographymediated heterogeneity of soil nitrogen and light at the forest floor. Ecol Res 18, 559-571.

Templer P H and Dawson T E 2004 Nitrogen uptake by four tree species of the Catskill Mountains, New York: Implications for forest N dynamics. Plant Soil 262, 251-261.

Templer P H, Lovett G M, Weathers K C, Findlay S E and Dawson T E 2005 Influence of tree species on forest nitrogen retention in the Catskill Mountains, New York, USA. Ecosystems 8, 1-16.

Tischner R 2000 Nitrate uptake and reduction in higher and lower plants. Plant, Cell and Environment $23,1005-1024$.

Tischner R and Kaiser W 2007 Nitrate assimilation in plants. In Biology of the Nitrogen Cycle. Eds. H Bothe, S J Ferguson and W E Newton. pp 283-304. Elsevier, Amsterdam.

Tjoelker M G, McLaughlin S B, Dicosty R J, Lindberg S E and Norby R N 1992 Seasonal variation in nitrate reductase activity in needles of high-elevation red spruce trees. Can J For Res 22, 375380.

Tokuchi N, Hirobe M and Koba K 2000 Topographical differences in soil N transformation using ${ }^{15} \mathrm{~N}$ dilution method along a slope in a conifer plantation in Japan. J For Res 5, 13-19.

Tokuchi N, Takeda H and Iwatsubo G 1993 Vertical changes in soil solution chemistry in soil profiles under coniferous forest. Geoderma 59, 57-73.

Tokuchi N, Takeda H, Yoshida K and Iwatsubo G 1999 Topographical variations in a plant-soil system along a slope on Mt Ryuoh, Japan. Ecol Res 14, 361-369.

Troelstra S R, Wagenaar R, Smant W and De Boer W 1995 Soil nitrogen transformations and nitrate utilization by Deschampsia flexuosa (L.) Trin. at two contrasting heathland sites. Plant Soil 176, 81-93.

Velthof G, Van Groenigen J, Gebauer G, Pietrzak S, Jarvis S, Pinto M, Corre W and Oenema O 2000 Temporal stability of spatial patterns of nitrous oxide fluxes from sloping grassland. J Environ Qual 29, 1397-1407.

Zeller B, Recous S, Kunze M, Moukoumi J, Colin-Belgrand M, Bienaime S, Ranger J and Dambrine E 2007 Influence of tree species on gross and net N transformations in forest soils. Ann For Sci 64, 151-158. 


\section{FIGURE CAPTIONS}

Figure 1 Changing environmental conditions for understory plant species and vegetation along a slope gradient (plot A). (a) Microtopography depicted by slope inclination in each $1 \times 3-\mathrm{m}$ subplot; (b) canopy cover ratio as an index of light conditions for the understory layer in each subplot; (c) diameter at breast height (DBH) of overstory Cryptomeria japonica [0; modified from Tokuchi et al. (1999)] and fine root biomass [hatched bar; modified from Kasuya and Shimada (1996)]; (d) thickness of the organic layer. Mean thickness at the eastern and western ends of the plot is depicted for the L (litter; closed area) and $\mathrm{F}+\mathrm{H}$ (humus) layers (hatched area). Figure modified from Hobara and Tokuchi (1998); (e) soil pH $\left(\mathrm{H}_{2} \mathrm{O}\right)$ measured in August 1995 [ $\triangle$; Hirobe et al. (1998)], and July 1992 (a; Yoshida unpublished data); (f) soil water content measured in August 1995 [ $\triangle$; Hirobe et al. (1998)], May 1993 [ \ ; Kasuya and Shimada (1996)], and July 1992 (๘; Yoshida unpublished data); (g) gross soil $\mathrm{N}$ mineralization (hatched bar) and nitrification rates (closed bar); (h) net soil $\mathrm{N}$ mineralization (hatched bar) and nitrification rates (closed bar). (g) and (h) are modified from Tokuchi et al. (2000). (i) Numbers of trunks $(-)$ and species $(\bigcirc)$ in $1 \times 3-\mathrm{m}$ subplots; and (j) distributions of four dominant understory species, viz., L. triloba, P. japonica, H. hirta, and L. stellipilum. The sizes of circles reflect numbers of stems, as indicated in the figure key.

Figure 2. Spatial distribution of dominant understory species and soil trait regarding $\mathrm{N}$ transformation on the mid slope (plot B). The number of stems is represented by the sizes of circles for (a) H. hirta, (b) P. japonica, and (c) L. triloba. Circle size represents (d) \% soil nitrification. Figure (d) is modified from Hirobe et al. (1998).

Figure 3. Seasonal changes in (a) leaf $\mathrm{N}$ concentrations, (b) leaf $\mathrm{NO}_{3}^{-}-\mathrm{N}$ concentration, (c) leaf NRA in four dominant understory species along the study slope, and (d) inorganic $\mathrm{N}$ pool sizes and (e) $\mathrm{NO}_{3}{ }^{-}$ $-\mathrm{N}$ pool sizes in soil samples associated with the four species. Leaves of the four dominant species and associated soils were investigated simultaneously for L. stellipilum $(\bigcirc), H$. hirta $[(\bullet)$, . japonica $(\triangle)$, and L. triloba $(\times)$. Bars represent SDs. See Appendix 2 for the results of statistical analysis.

Figure 4. Soil nitrification along different sections of the slope gradient [data from Tokuchi et al. (2000)]. Relationships between gross and net nitrification rates are depicted for soil from the lower slope where L. stellipilum was dominant $(\bigcirc)$, soil from the middle slope where $H$. hirta was dominant $(\bullet)$, and soil from the upper slope where P. japonica was dominant $(\triangle)$. Bars show SEs for net nitrification rate. 


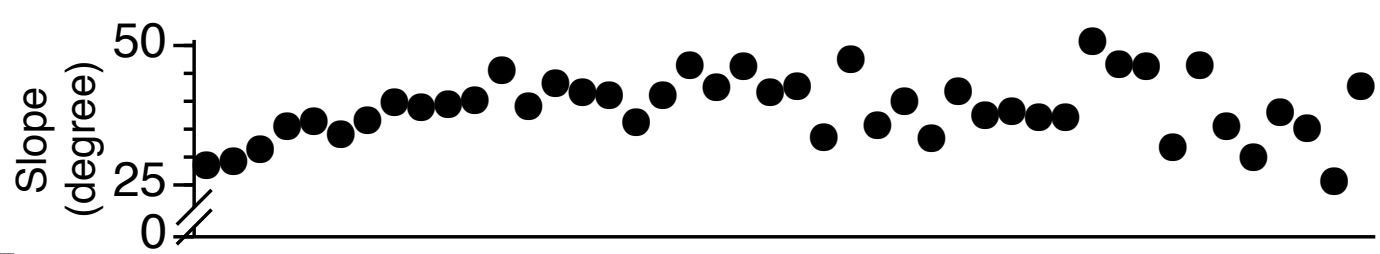

(a)

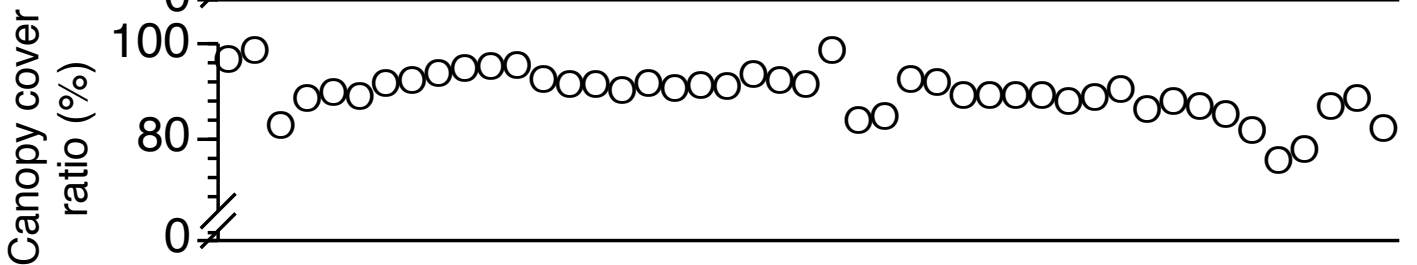

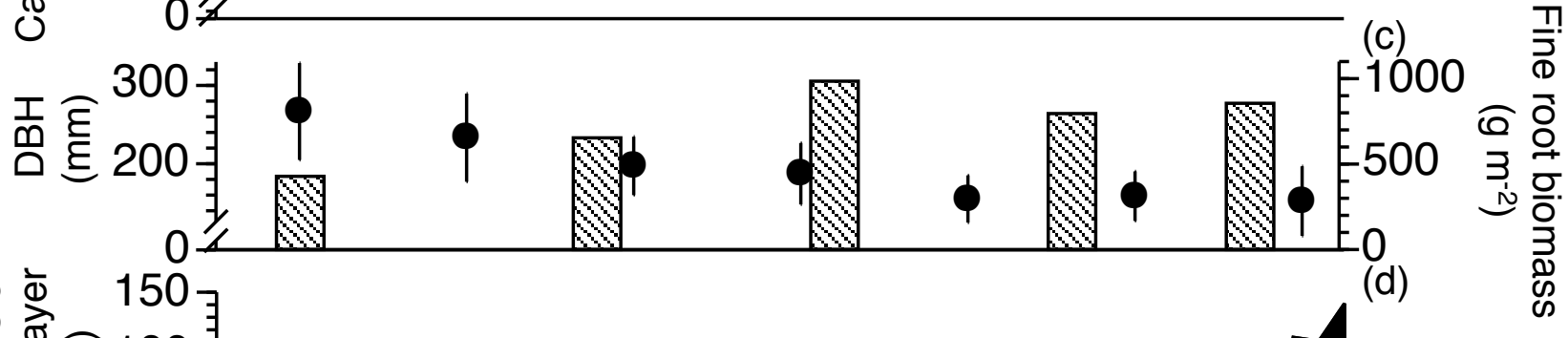

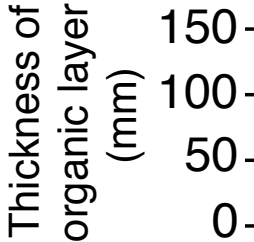

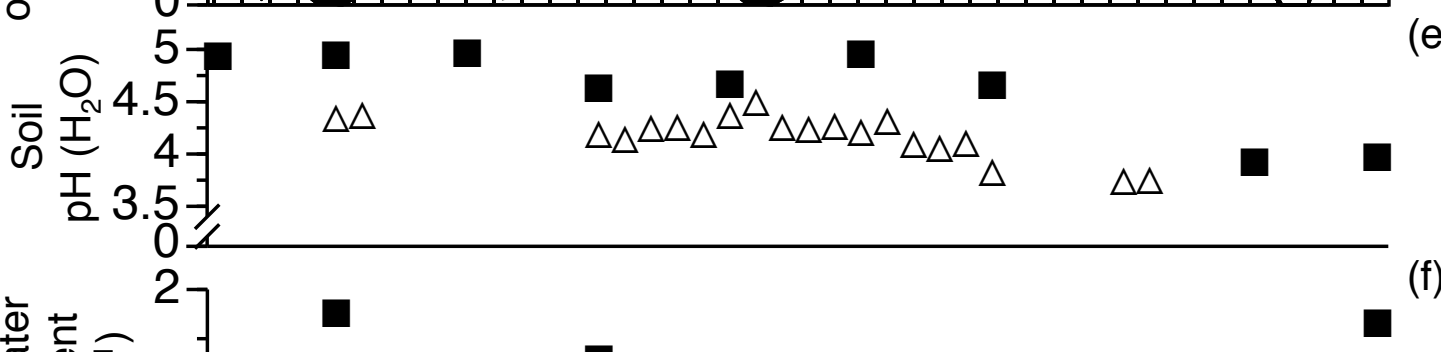

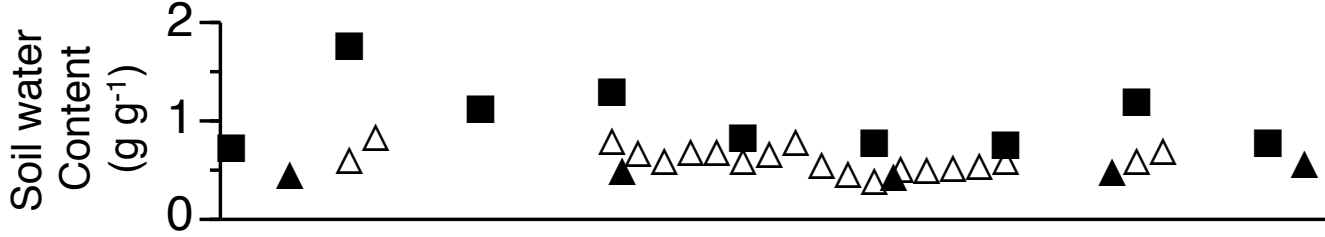

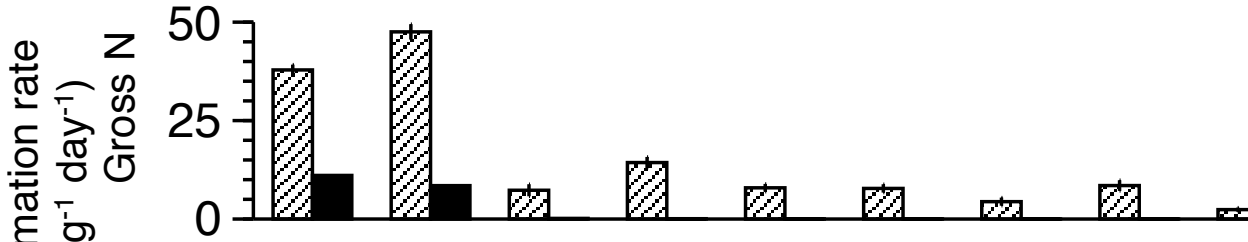

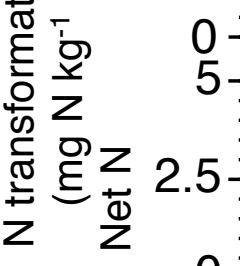

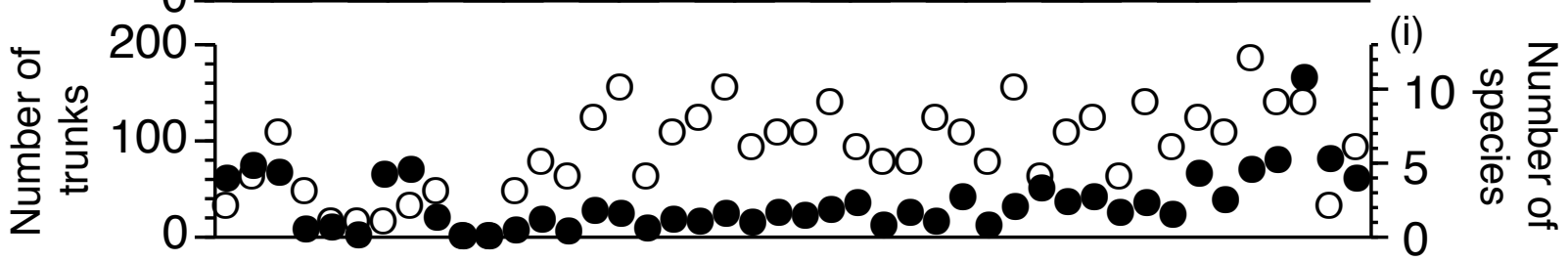

L. triloba
P. japonica
H. hirta
L. stellipilum

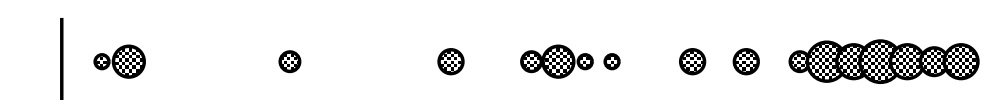

Fig. 1

;

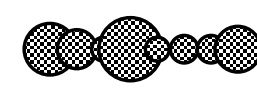

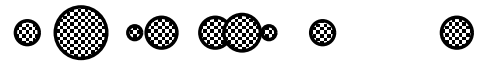

(j)

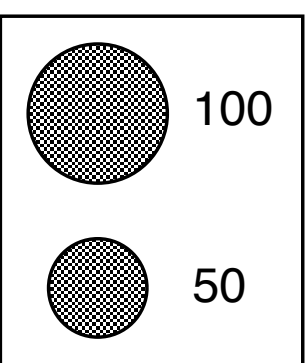




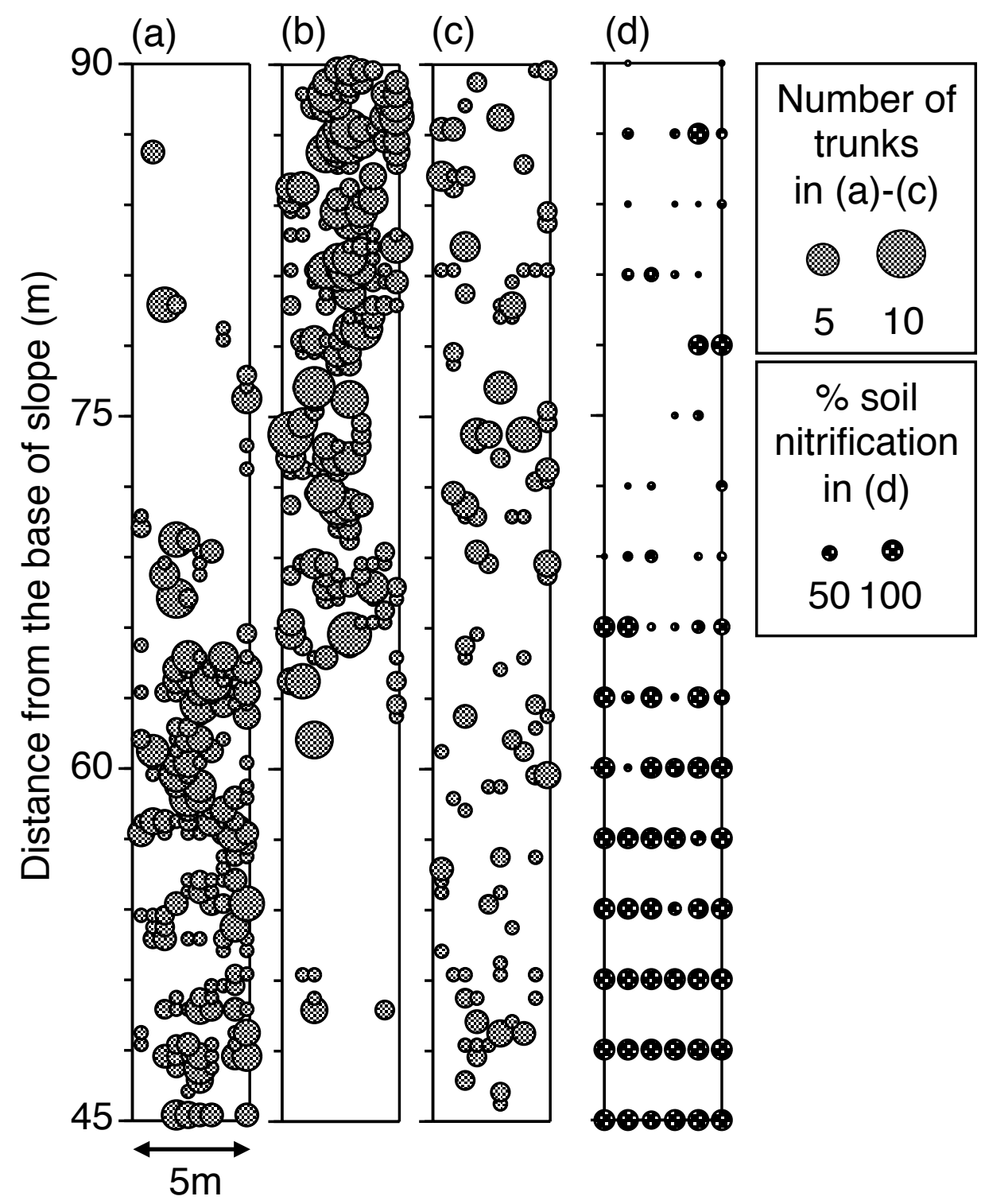

Fig. 2 


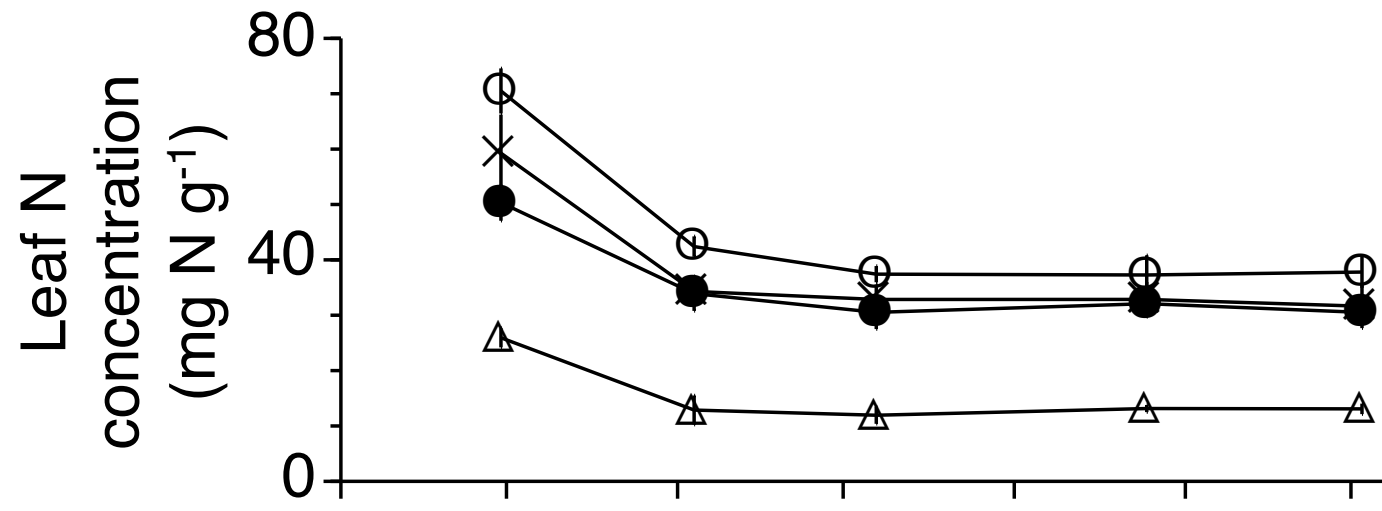

(a)
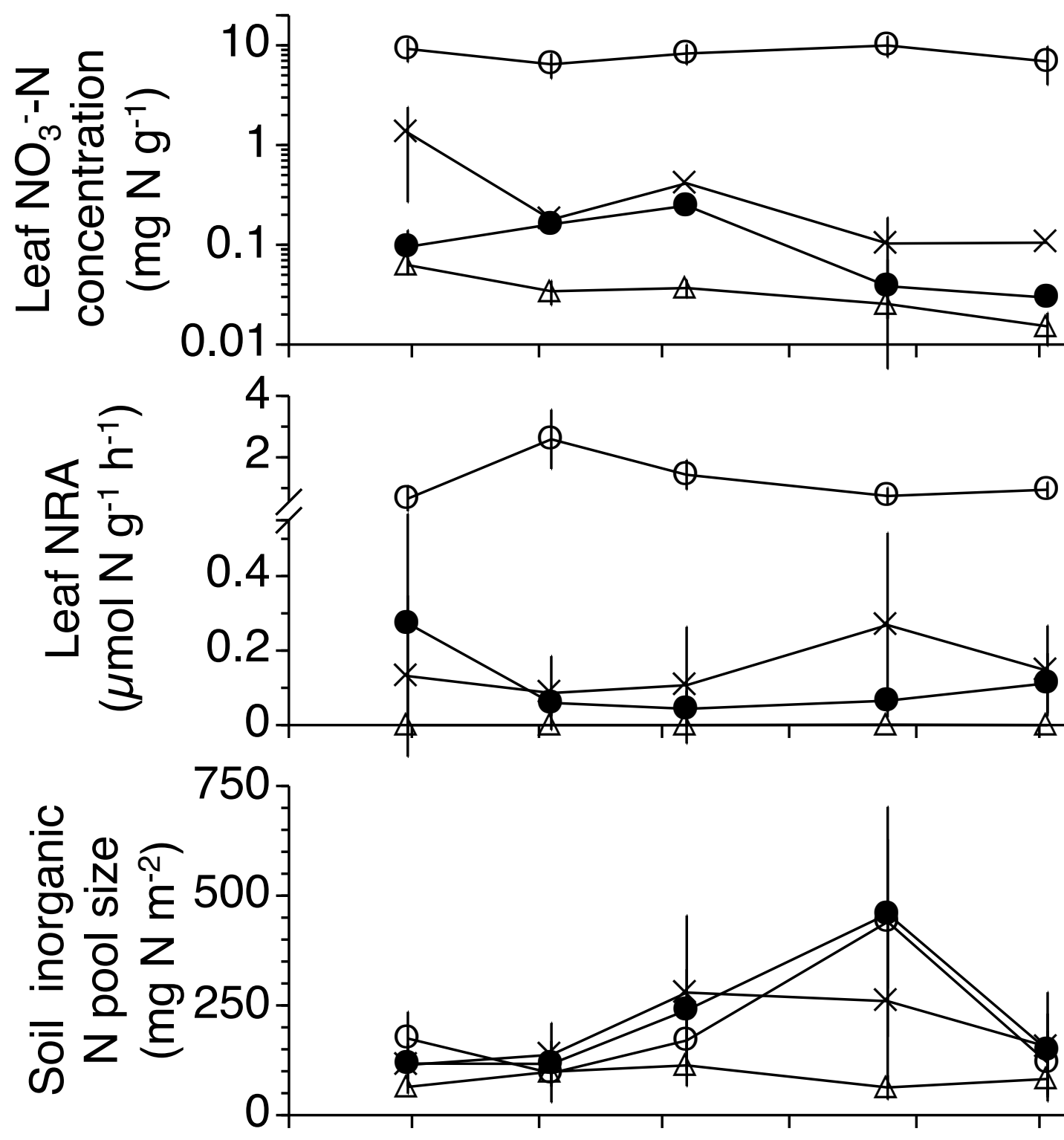

Fig. 3

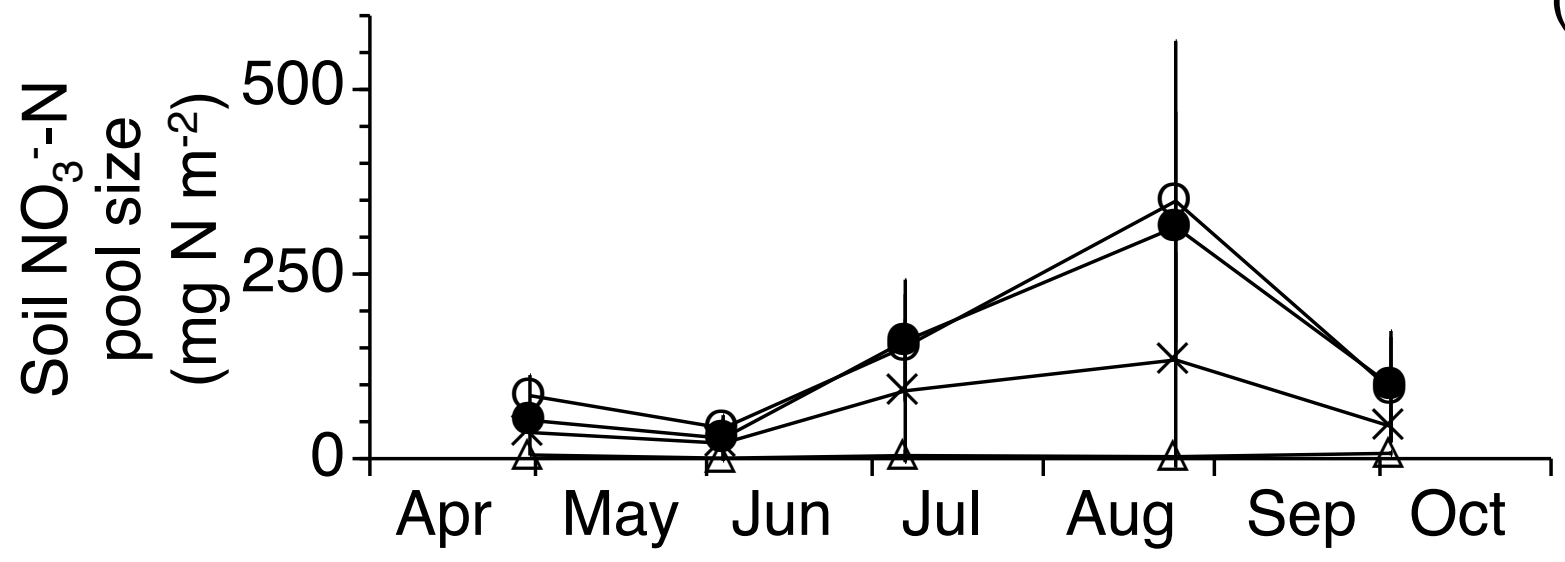




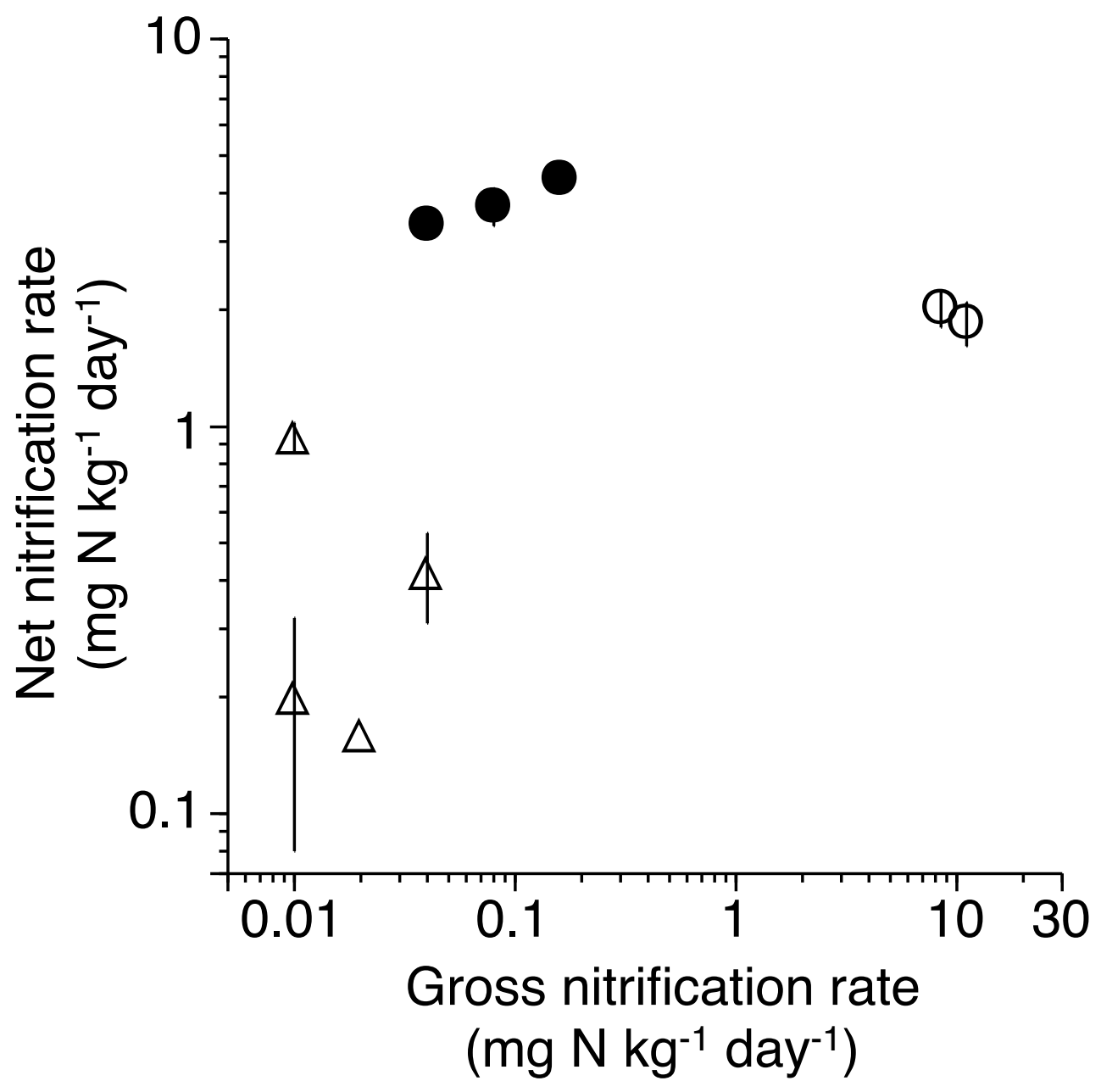

Fig. 4 
Table 1. Spatial distribution parameters for $H$. hirta, $P$. japonica, and L. triloba in plot B

\begin{tabular}{lccc}
\hline \multicolumn{1}{c}{ Species } & $I_{a}$ & Mean $v_{i}$ & Mean $v_{j}$ \\
\hline H. hirta & $5.91^{\dagger}$ & $6.01^{*}$ & $-6.38^{*}$ \\
P. japonica & $7.44^{\dagger}$ & $7.44^{*}$ & $-7.90^{*}$ \\
L. triloba & $1.08^{\#}$ & $0.97^{\text {ns }}$ & $-1.03^{\text {ns }}$ \\
\hline
\end{tabular}

$\dagger$, significantly aggregated distribution at $P<0.05$; \#, not significantly different from random distribution.

*, significant patch or gap, $P<0.05$; ns, no significant patch or gap.

Table 2 Spatial associations among $H$. hirta, $P$.

japonica, and L. triloba in plot B.

\begin{tabular}{|c|c|}
\hline Species & $X$ \\
\hline H. hirta vs. P. japonica & $-0.48^{t+}$ \\
\hline H. hirta vs. L. triloba & $-0.20^{\dagger+}$ \\
\hline P. japonica vs. L. triloba & $0.04^{\# \#}$ \\
\hline
\end{tabular}




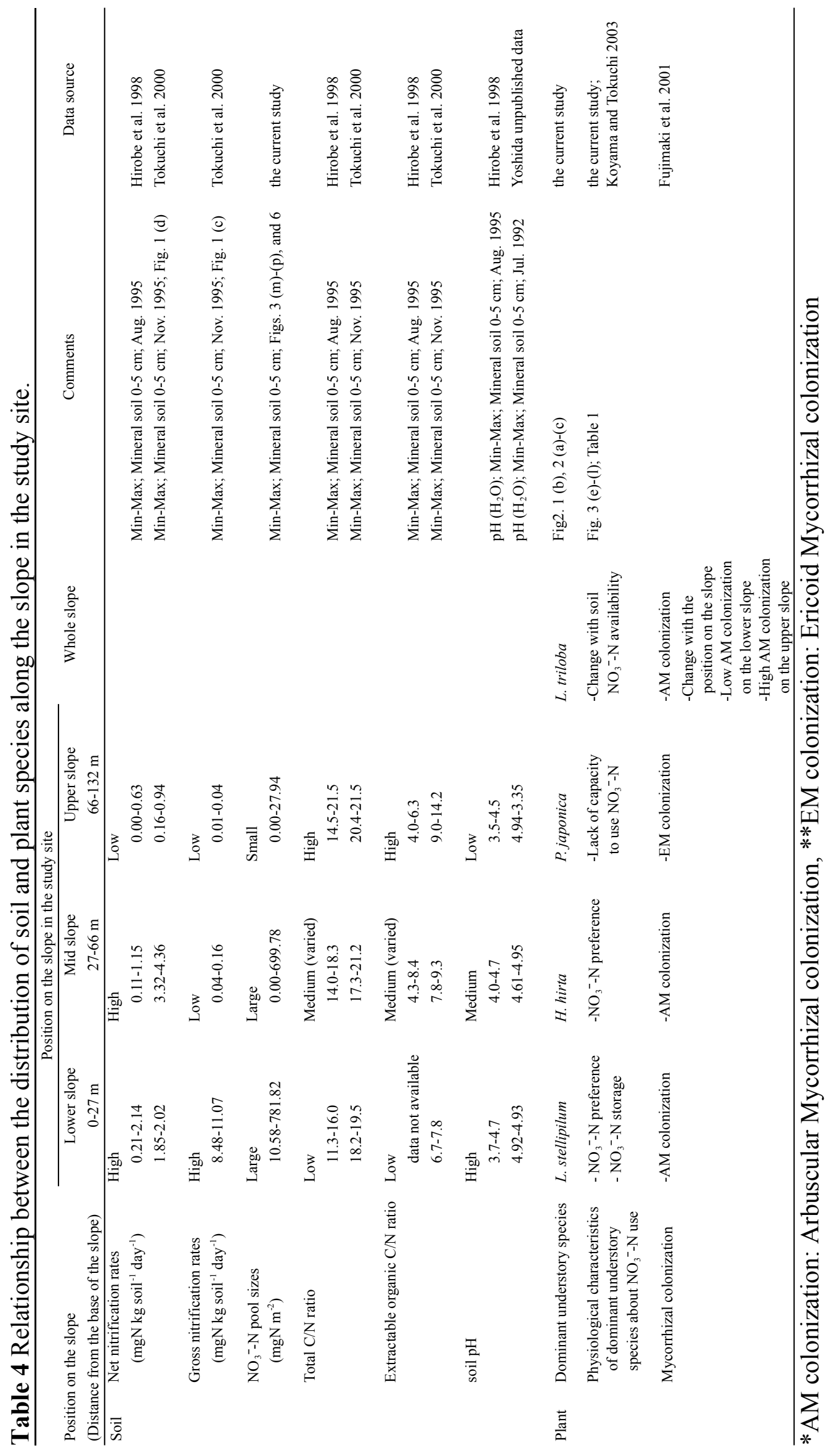


Table 3 Relationships between soil N pool size and leaf traits examined by Pearson's correlation coefficients.

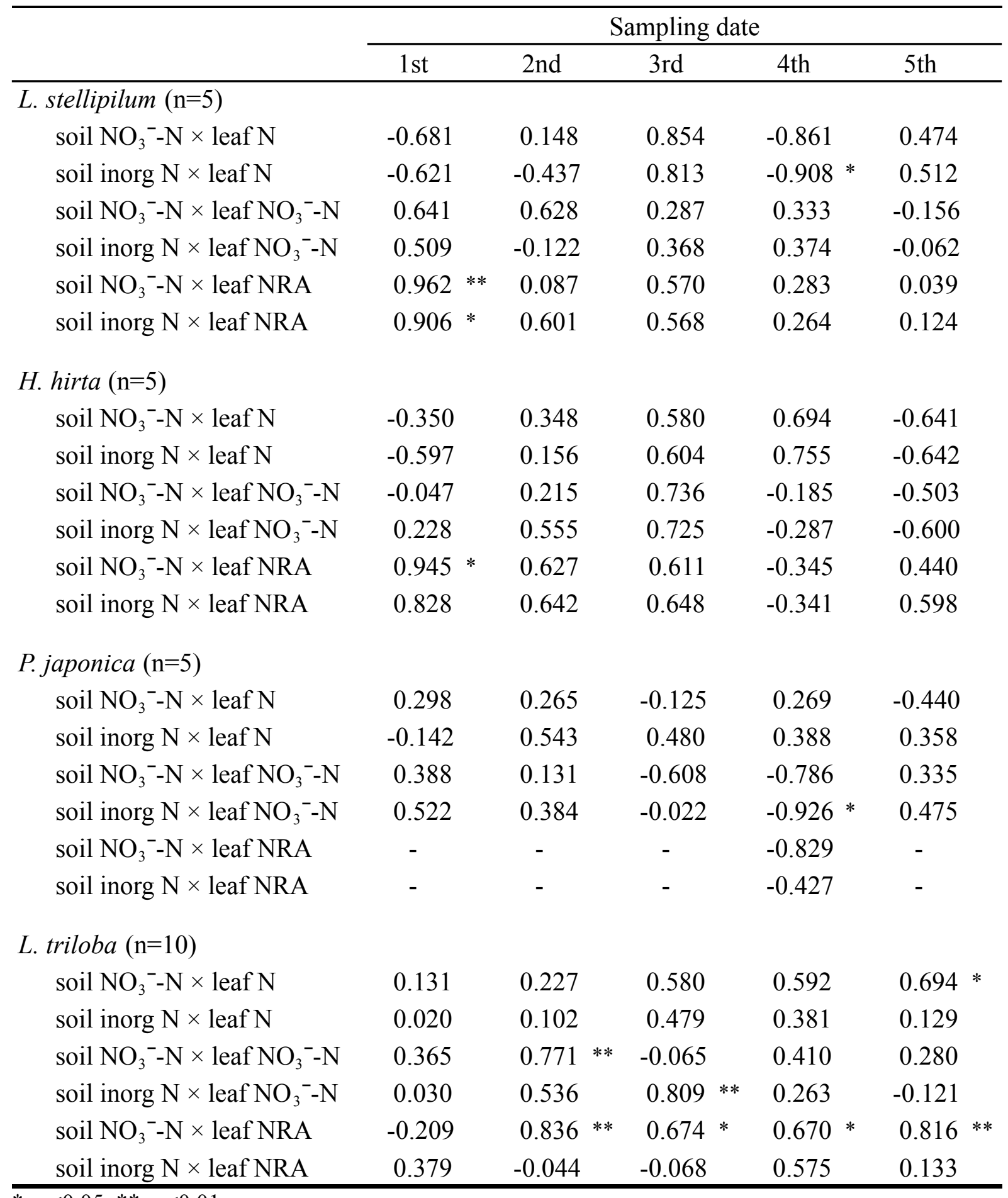

$*: \mathrm{p}<0.05, * *: \mathrm{p}<0.01$ 
Appendix 1 Plant species distribution in plot-A. The number of trunks was recorded for the plants taller than $10 \mathrm{~cm}$ in each subplot.

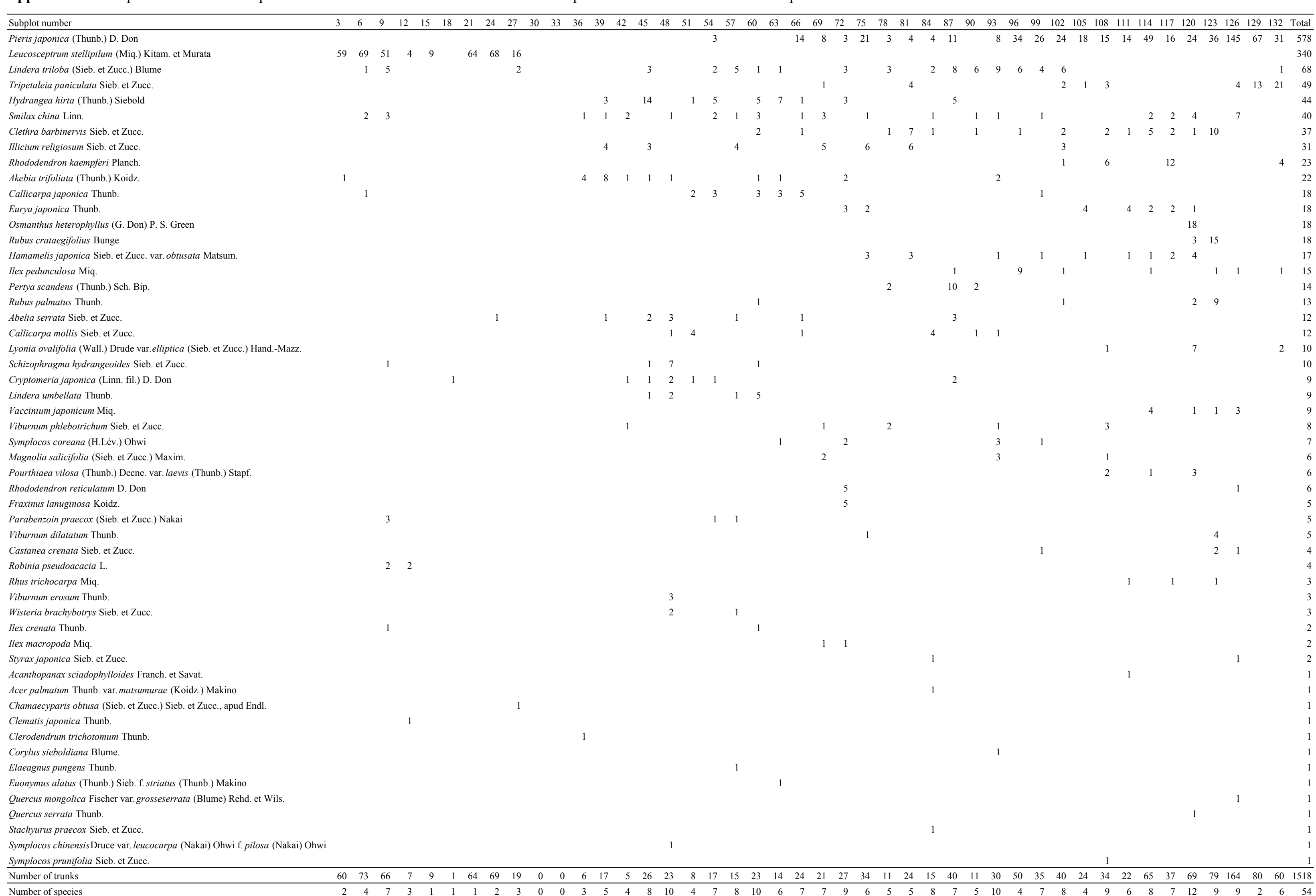


